\title{
Bringing a Gender Perspective to the Peace Table: Women in Myanmar's Peace Process
}

\author{
By Zin Mar Thein
}

300292687

A thesis submitted to the Victoria University of Wellington in partial fulfilment of the requirements

for the degree of Master in International Relations (MIR)

School of History, Philosophy, Political Science and International Relations Victoria University of Wellington 
Ethnic division and inequality lie at the heart of Myanmar's internal conflicts. In these conflicts, ethnic women are the most vulnerable group based on their ethnicity and gender. They are not only victims of violence, they have also been systematically marginalized from formal peace processes under both military and civilian governments. This thesis uses a feminist constructivist approach to examine the gendered role of women and girls in Myanmar society and the impacts of armed conflicts on women and girls in the conflict areas. The thesis discusses the history of ethnic divisions in Myanmar since independence in 1948, various peace initiatives pursued by Myanmar governments and the experiences of women and girls during conflict and their involvement in the more recent peace-building process. Drawing on extensive interviews with officials, politicians and civil society representatives, the thesis argues that if a sustainable and just peace is to be built in Myanmar, women need to be given a greater role. It also identifies obstacles that need to be overcome if women are to participate effectively in both formal and informal peace processes. 


\section{Table of Contents}

Abbrevation

1 Introduction 1

2 Chapter One: War, Peace and Feminism 3

Gender, Sex and Socialization 3

Feminist and Peace Theory: A Gendered Approach to Security and Peace 7

Experiences of Women and Contemporary Armed Conflicts 12

Women's Participation in Peace Processes 15

Adoption of Resolution 1325 and Women's Participation in Peace 17

3 Chapter Two: Internal Conflicts in Myanmar 19

Colonization, Independence Struggle and the Spirit of Pinlong 19

State Formation Conflicts, Forced Assimilation and Burmanization 21

Policy of State Religion, Constitutional Crisis and Ethnic Inequality 23

Socialism, Militarization and National Language Policy 24

The Military Regime and the Ethnic Politics 26

The Reform Government and the Ongoing Ethnic Conflicts 28

4 Chapter Three: Impacts of Armed Conflicts on Women and Girls 31

Threats to Personal Safety and Socio-Economic Dimensions 31

Violence against Women and Girls 33

Health of Women and Girls 34

Women and Girls as Refugees and Internally Displaced Persons 35

5 Chapter Four: Peace Processes in Myanmar 37

Peace Process under the Military Government 37

Understanding the Current Peace Process in Myanmar 41

Key Challenges to the Peace Processes 43

6 Chapter Five: Women in Peace Processes of Myanmar 45

Gender Analysis on the Current Peace Process 45

Challenges to Women's Participation in Formal Peace Processes 54

Bringing Gender Perspective to Myanmar's Peace Table 58

7 Conclusion $\quad 61$

Lists of Interviewees

Bibliography 


\section{List of Abbreviations}

AFPFL Anti-Fascist People's Freedom League

BCP Burmese Communist Party

BGF Border Guard Force

BSPP Burmese Socialist Progamme Party

CEDAW Convention on the Elimination of all Forms of Discrimination Against Women

CNF Chin National Front

DAB Democratic Alliance of Burma

DKBA Democratic Karen Buddhist Army

KIA Kachin Independence Army

KIO Kachin Independence Organization

KNPP Karenni National Progressive Party

KNU Karen National Union

KWAT Kachin Women Association Thailand

MI Military Intelligence

MPC Myanmar Peace Center

MSA Military Security Affairs

NCCT Nationwide Ceasefire Coordination Team

NDAA National Democratic Alliance Army

NDAK National Democratic Army- Kachin

NDF National Democratic Front

NLD National League for Democracy

NMSP New Mon State Party

NSAG Non-State Armed Groups

NSPAW National Strategic Plan for the Advancement of Women

RCSS Restoration Council of Shan State

SLORC State Law and Order Restoration Council

SPDC State Peace and Development Council

SSA Shan State Army 


$\begin{array}{ll}\text { ULPC } & \text { Union Level Peace Committee } \\ \text { UN } & \text { United Nations } \\ \text { UNFC } & \text { United Nationalities Federation Council } \\ \text { UNIFEM } & \text { United Nations Development Funds for Women } \\ \text { UPWC } & \text { Union Peace Working Committee } \\ \text { USDP } & \text { Union Solidarity and Development Party } \\ \text { UWSA } & \text { United Wa State Army } \\ \text { WLB } & \text { Women League of Burma } \\ \text { WON } & \text { Women Organization's Network }\end{array}$




\section{Introduction}

In Myanmar, a six-decade-long internal conflict has been driven and fuelled by ethnic division and inequalities. As a consequence of policies of Burmanization and militarization practiced by the country's military government up until 2011, people in ethnic areas have faced various forms of human rights violations. Among them, women and girls have suffered disproportionately from armed conflict because of their status and roles in society. Armed conflict puts an extra burden on women and girls on top of their traditional responsibilities. Sexual violence against women and girls in ethnic areas has become a feature of armed conflict in Myanmar.

When the newly elected civilian government came to power in 2011, new peace initiatives were launched and ceasefire agreements were reached with many ethnic armed groups. However, despite this, cases of sexual violence are increasingly reported. Alarmingly, protection for women and girls in the conflict areas has not even been discussed in peace negotiations.

This thesis seeks to explore efforts build a sustainable peace in Myanmar with a particular focus on the absence or underrepresentation of women in the formal peace talks. It has three aims. First, it seeks to provide a better understanding of the nature of internal conflicts in Myanmar. Second, it shows how women and girls are affected by these conflicts: the ways in which their traditional gender roles are changed and how they are increasingly targets for sexual violence. Third, the thesis argues there is a link between the marginalization of women from the formal peace talks and the failure to achieve a long-lasting peace. It argues that too many of the key stakeholders in Myanmar's peace process undervalue the role of women and that there is an urgent need to include greater women's representation at all stages of the peace process if a sustainable peace is ever to be agreed.

\section{Methodology}

This thesis utilizes methods of qualitative data analysis to support its analysis. It draws heavily on the secondary literature on conflict in Myanmar including books, journals, newspaper articles, reports, publications, and transcripts of official remarks. It supplements this material with evidence drawn from extensive interviews with people involved in the working groups from the various peace negotiation parties, women's and peace organizations, and Myanmar politicians. These semi-structured 
interviews, which took place with approval of the Victoria University Human Ethics Committee, took place in Nay Pyi Taw and Yangon between November 2014 and January 2015. A list of the interviewees is included in Appendix A.

Although there is a large literature on the topic of women, conflict and peace, there is little written on Myanmar as a case and there were challenges researching this topic.

Since "peace" is a sensitive issue in Myanmar, some people are not willing to discuss it. Although interviews were conducted with some people from the country's parliaments, the Myanmar Peace Centre, women organizations and activist groups, this study was not able to include the opinions of representatives from the ethnic armed groups because of security reasons, difficulties in travel and time constraints. However, some previously published interviews with people from these armed groups are cited in this paper to try to generate a broader perspective.

The thesis is organized in five chapters. The first, "War, Peace and Feminism" provides an overview of the literature on theories of feminism and peace and the importance of women's inclusion in peace processes. The second chapter, "Internal Conflicts in Myanmar" examines the root causes of the various internal conflicts in Myanmar. Chapter three, "Impacts of Armed Conflicts on Women and Girls" emphasizes the experiences of women during and post-conflict periods. It makes the point that Myanmar's armed conflicts have different impacts on women and girls than they do on men and boys. The fourth chapter, "Peace Processes in Myanmar" compares peace initiatives under the military junta and the civilian government and analyzes the obstacles that have so far prevented them from succeeding. Finally, chapter five, "Women in Peace Processes" analyzes the role of women in the current peace process, concluding they are strikingly absent.

The thesis concludes that a gender perspective is an important missing element in the current peace negotiations. It argues it is essential to include such a perspective in order to protect and secure the lives of women in conflict areas and to forge a truly sustainable peace. By sharing its findings, it is hoped that the thesis can make a small contribution to the literature on women, peace and security an improved understanding of the impacts of Myanmar's armed conflicts on women and girls. 


\section{Chapter One: Women, Peace and Security}

According to Oxford dictionaries, "Feminism is the advocacy of women's rights on the ground of the equality of sexes" while peace is defined by a situation when "social justice" prevails. Both feminism and peace are structured around the concept and logic of domination. Furthermore, the differences in experience and vulnerabilities between women and men during conflicts also link feminism to peace, arguing the necessity of women's inclusion in peace table. Again, peace could provide opportunities for feminists to support gender equality and to increase women's participation in public sphere. Therefore, this chapter explores feminist arguments of essentialism and constructivism in relation to the concept of war and peace. This discussion is in five sections. The first section discusses the difference between sex and gender, and explores how women's biology and social constructions contribute to the idea that women are innately "peaceful" and have an "aversion to violence". The second section discusses feminist theory, especially theories relating to the power divisions between women and men in accordance with their gender roles and how the phenomenon of "war-making" and "peace-building" reflects in these power relations. The third section focuses on the different experiences and vulnerabilities of women during contemporary conflicts, signifying the importance of "violence against women" to be addressed at the formal peace talks. The fourth section looks at the presence of women in peace negotiations in order to point out the need of gender mainstreaming to achieve a sustainable peace. Finally, section five will discuss the emergence of United Nations Security Council Resolution 1325 and its connection to the inclusion of women in politics and peace processes.

\section{Gender, Sex and Socialization}

Although they are interrelated, the perceptions of gender and sex are not interchangeable. Steans $(1998,10)$ differentiates between these two concepts that "gender refers not to what men and women are biologically, but to the ideological and material relations which exist between them". Accordingly, sex is determined by genital, while a life-long practise of socialization defines gender. This notion is supported by Goldstein $(2001,2)$ who argues that "sex" is defined biologically while "gender" is referred culturally. Women and men are associated with certain sexes, but are demanded to perform different social roles and responsibilities that are 
constructed by their gender, not by their predetermined biological sex. In this regard, women's biologically inherent and socially constructed "peacefulness" is linked with "peace process" while men are argued to be inherently and socially "aggressive".

An essentialist feminist explanation argues there is a connection between women and peace, based on a woman's natural reproductive role. The practises and capabilities of women as mothers are appealed to be reproducing peace-making skills. Women have committed themselves to the cause of peace, not only in the search for better conditions for women, but mainly for their families and children. ${ }^{1}$ This notion is reinforced by their nature as care-givers and nurturers and used to unify women as a powerful source for resistance. ${ }^{2}$ Additionally, essentialist feminists argue that women naturally avoid violent means and prefer peaceful methods for conflict resolution as a result of their inherent reproductive roles in the society. ${ }^{3}$ It is also argued that men are more associated with the nature of competition and rivalry. ${ }^{4}$ That is why, essentialists claim that their inherent peaceful natures lead women to hold the views against any forms of violence.

From essentialist's perspective, gender gaps are so deeply rooted that the gap cannot be narrowed much. ${ }^{5}$ While the features of men and women are defined by their biological differences and are unalterable, essentialists argue that it is unlikely for women to become aggressive and men to become peaceful. ${ }^{6}$ This essentialist's perception leads an argument that women, in general, would exert more effort to prevent or reduce the risks of armed conflicts if they could equally represent in society and politics. ${ }^{7}$ Although the biological differences define women and men in general, later are influenced by their socially constructed roles. Likewise, despite their reproductive role to widespread peacefulness, women are claimed to train their children according to the patriarchal value of their society. ${ }^{8}$

Meanwhile, contemporary theorists focus more on their social construction and differences. Tickner (1992) argues that the term gender refers to "a set of culturally

\footnotetext{
${ }^{1}$ Arino (2010), p. 19

${ }^{2}$ Shiva (1988), p. 42

${ }^{3}$ Melander (2005), p. 697

${ }^{4}$ Tessler \& Warriner (1997), p.185

${ }^{5}$ Fukuyama (1998), Goldstein (2001), ch. 5, Ruddick (1989)

${ }^{6}$ Nincic \& Nincic (2002), p. 551

${ }^{7}$ Melander (2005), p. 697

8 McCarthy, Hagan \& Woodward (1999)
} 
shaped and defined characteristics associated with femininity and masculinity". 9 Conceptions of masculinity and femininity have been socialized and exercised through childhood's role-learning. This role-learning forces young boys to engage in more manly activities, but discourages them from dealing with household activities. They have learned to reject things that seem to be feminine and place themselves in masculine activities. ${ }^{10}$ In contrast, "women are taught to be less competitive and more focused on issues of interdependence and egalitarianism". 11 Consequently, these childhoods" "role playing" becomes normalized throughout childhood and gradually deeply roots as gender roles into adulthood since children are trained to acquire specific behaviours and qualities according to their own genders. ${ }^{12}$

More comprehensively, one's biological identity shape gender characteristics, which could be varied across time and place. In this regard, constructivist argument focuses on how socially constructed gender roles influence attitudes towards violence and the use of force. In this essence, constructivists argue that female opposition to violence and male tendency to violence are more associated with their socially constructed certain definition of femininity and masculinity, rather than biological differences of being female and male. ${ }^{13}$

According to constructivist theorists, gender roles demand men to prepare for specific tasks such as warriors and assign women at feminine roles such as nursing and caring. Consequently, "these traditional gender roles not only prescribe male violence as a means of establishing domination and protecting honour but also legitimize the subordination of women". 14 "Most men are trained from boyhood to suppress emotions and withstand pain. Femininity is the subordinated category and defined more in terms of submission and empathy". ${ }^{15}$ Historically, the ultimate test for manhood is socially defined to be "warlike", and those who failed to meet this criterion is shamed and lowered to the position of women and girls. ${ }^{16}$ Historically, men control the area of security including war and war making so that male aggression is the main cause of war. Throughout recorded history, wars have been

\footnotetext{
${ }^{9}$ Tickner (1992), ch. 1

${ }^{10}$ Baksh (2005), p. 18

${ }^{11}$ Caprioli \& Boyer (2001), p.5

${ }^{12}$ Pilcher \& Imelda (2004), p. 161

${ }^{13}$ Melander (2005), p. 698

${ }^{14}$ Tickner (1992), ch. 1; Goldstein (2001), ch.5

${ }^{15}$ Melander (2005), p. 698

${ }^{16}$ Melander (2005), p. 698
} 
fought by men. Basically, men are assumed as warlike when compared to the nonviolent and anti-militarist role of women. ${ }^{17}$ Moreover, the women and peace hypothesis speculates that women are more peaceful and supportive in conflict situations than their male counterparts are, and are more likely to seek out a compromise or other alternative solution before resorting to violence. ${ }^{18}$ Also, women are capable of building bridges in divided societies where hatred and division are deeply rooted.

Women can bring key players together from each community to work on resolving problems and search new ways of living together. ${ }^{19}$ In essence, feminist's constructivism is linked to peace by emphasizing the women's normative aversion to violence and arguing for more equal gender roles in peace processes.

Very often, constructivism appears much more persuasive than essentialism. Although essentialist feminists keep their notion of "male's aggression or hostility as the source of conflict", they are no longer confident to connect peace with female's inherent "motherhood" and "maternal thinking". In reality, essentialist's hypothesis of "women and peace" is challenged by the experiences of female fighters. The concept of female inherent peacefulness is shattered in the wake of acknowledging women's experiences in war as active fighters. ${ }^{20}$ More importantly, the notion of "motherhood" and "maternal thinking" is criticised as a dangerous moral superiority. Accordingly, many point out that mothers sacrifice their children and husbands in war, and the mother's acceptance of death as well as their active part in organizing to motivate nationalism and militarism. ${ }^{21}$

Also, feminist constructivism challenges the idea that women's peacefulness is not genetic by pointing to instances of female world leaders such as Indira Gandhi or Margaret Thatcher who were considered neither "soft" nor "feminine". In addition, constructivist's notion of men's warlikeness reinforce feminist's approach to peace process, however, the gender stereotype that categorizes women as passive, victims and emotional, hinders feminist's claims for equal participation, keeping women out

\footnotetext{
${ }^{17}$ Eisler \& Loye (1986); Weber (2006)

${ }^{18}$ Tessler, Nachtwey, and Grant (1999); Maoz (2009)

${ }^{19}$ Cockburn (2007), Villellas Arino (2010)

${ }^{20}$ Weber (2006), p.6

${ }^{21}$ Ibid, p. 9
} 
of power. $^{22}$ Also, it is argued that although they are not directly taking part in fighting, women support warlike men physically and emotionally because men's capabilities as strong warriors are proved in the presence of women and girls as the audience. Throughout history, men's military activities are loyally supported by women by taking the roles as mothers and wives, perpetuating war rather than their supposed peace building potentials. ${ }^{23}$

Generally, both essentialism and constructivism argue women to be more peaceful in comparison with their male counterparts because of the differences in biological nature and socially constructed characteristics. However, as above noted, constructivists' argument is much more convincing and employed by the United

Nations in mainstreaming gender perspective in the peacekeeping operations. ${ }^{24}$ In this regard, women's aversion to the use of violence in conflict resolution and their gender roles are well-recognized and has encouraged feminist's attempt in achieving gender equality in the peace processes in which women are underrepresented and even marginalized.

\section{Feminist and Peace Theory: A Gendered Approach to Security and Peace}

Peace studies emerged after the end of the Second World War, especially in the outbreak of the Cold War. It focuses on the elimination of war, which was essentially demanded during the East-West ideological confrontation and nuclear arms race among the superpowers. Then, the scope of peace was expanded and referred to not only the non-emergence of war, but also absence of all forms of violence. It is also defined that peace is the condition for conflicts to be transformed in creative and non-violent means. 25

Norwegian scholar Johan Galtung formulates a theory of peace in which he categorizes violence in three different forms; personal, structural and cultural violence. He describes personal violence as direct violence which is the most common form, and structural and cultural violence as indirect violence which have less damaging ways. He also regards of peace in two definitions; negative peace which refers to the non-emergence of direct violence and positive peace which

\footnotetext{
${ }^{22}$ Tickner (1999)

${ }^{23}$ Tickner (1992); Goldstein (2001); Melander (2005)

24 Jimenez (2009), ch.2

${ }^{25}$ Galtung (1996), p. 77
} 
prevails social justice. ${ }^{26}$ His concept of "positive peace" is widely adopted by many actors working in peacebuilding and is linked to "the recent changing concept of international security to incorporate not just military and political security but also human security and development". 27 In its broader sense, peacebuilding can be defined as the advancement of development, justice and equality, and free from any kind of violence. ${ }^{28}$

Since 1990s, the war has changed in its nature into intra-state conflicts in which civilians are increasingly targeted. As a result, the roles and responsibilities of the international institutions such as UN peacekeeping have also changed, extending its original military operations and mediation between nation states to multidimensional missions which include "restructuring state's institutions, reorganizing the judiciary system, training the host's country police and armed forces, disarmament, demobilization and reintegration of former combatants, and organizing and monitoring electoral processes". ${ }^{29}$ Despite these efforts, sustainable (positive) peace remains distant for majority of world's population. There is a need for a different approach in order to take a more all-inclusive approach to peacemaking. Feminist theorists introduce a gender analysis into the arena of peacemaking. Therefore, constructivist feminists argue that gender difference shape not only different experiences, but also unequal power dynamics between women and men. ${ }^{30}$

A gender perspective to peacemaking is promoted by "gender-blindness" within peace process, maintaining that women are invisible in the politics. Also, it assumed that peace is built based on the experiences of men so that women are excluded physically and theoretically. Although it is supposed to be gender neutral in nature, feminists argue that women's exclusion in this area is directly associated with unequal power dynamics. ${ }^{31}$ Gender mainstreaming in peacemaking is inspired by arguments of constructivist feminists, claiming that life-long socialization, not biological sex, shapes gender characteristic. Accordingly, they don't accept notions that women are inherently fearful and could not engage in political processes. Also they argue that differences between women and men's attitudes towards war and

\footnotetext{
${ }^{26}$ Galtung (2005)

${ }^{27}$ CIDA (2002); Strickland \& Duvvury (2003), p. 6

${ }^{28}$ Barnett et al (2007)

${ }^{29}$ Bertolazzi (2010)

${ }^{30}$ Peterson (1998); Anderlini (2002)

${ }^{31}$ Tickner (1992)
} 
peace are designed by socialization since childhood. ${ }^{32}$ From their perspectives, there is a link between the assigned roles and the uneven power dynamics between women and men. In comparison with their male counterparts, female-identified roles are less recognized and rewarded. Male roles are largely concerned with leadership and decision-making positions. It also explains that the socially constructed female's passive, emotional and sensitive notions are justified to force their subordination. As a result, the unequal gender relations and power imbalance are rationalized because masculinity characteristics are most appreciated in politics. ${ }^{33}$ Also, most IR theories tend to suggest that feminist's characteristics are less suitable to conduct politics. Women are therefore excluded from political affairs physically and mentally.

Feminists are aware of the requirement to re-structure many important maledominated notions of politics (for instance, security) which are inaccessible for them since the underlying theories are embedded in patriarchal value. "National security studies attempts to explain the cause of war through a discourse that privileges a view based on hegemonic masculinity". ${ }^{34}$ In the recognition of the roles of women as ones being protected by the male soldiers, women's role in national security is rather ambiguous, keeping them out of power relations. Men's role as soldiers and their readiness to sacrifice their lives for their countries have been rewarded in many cultures throughout history since it is considered as the highest form of patriotism. ${ }^{35}$ In this regard, women who are excluded from the sphere of "war" are consequently also marginalized in broader power relations.

Security threats, conventionally refers to things threatening to national boundaries. However, these security concerns now are no more external. Conflicts break out within national territories with a higher rate of civilian causalities. These new wars, in other words, internal conflicts have become the most common form of violent conflicts, connected to human costs as well as economic loss.

Feminists believe that the reinterpretation of security is essential to highlight the connection between gender hierarchies and power dynamics and the interconnectedness of militarism, sexism and violence. ${ }^{36}$ As a result of sexism,

\footnotetext{
${ }^{32}$ Burris in Conover \& Shapiro (1993)

${ }^{33}$ Stean (1998), p. 11; Tickner (1992)

${ }^{34}$ Blanchard (2003), p. 1296

${ }^{35}$ Ibid.

${ }^{36}$ Blanchard (2003), p. 1296
} 
women and girls are discriminated based on their gender and their security is prioritized after men and boys' security. In this regard, feminists argue that human security, rather than military security, must be assured in order to address issues of violence. ${ }^{37}$ In the situations when the state fail to provide protection of women from violence, feminists theories introduce a new concept on the area of personal security and violence structure at different levels and empower women's movement for gender equality. ${ }^{38}$ Women and girls are the most vulnerable group in times of armed conflicts and terrorism due to their status and sex. Thus, Feminists call attention to experiences and vulnerabilities of women and girls during the conflicts, and lack of access to the formal peace processes as a result of gender hierarchies that exist in society. ${ }^{39}$ Feminists raise their concerns that women and girls' security is missed out in the discourse of human security. Based on these perspectives, two central themes can be analysed: “1) women's absence from decision-making positions that are central to peace-building; and 2) the impacts of armed conflict on women, gender relations, and gender roles". 40

In 2000, the United Nations Security Council enacted Resolution 1325 in order to endorse the necessity of a gender perspective to peace-making process. This resolution aims at strengthening the participation of women in formal peace-making activities. Also, it is utilized as a mechanism to achieve gender equality. ${ }^{41}$ However, according to UN Women, women remain largely marginalized from official peace talks where important policies about post-conflict reconstruction are formulated.

Despite explicitly international calling for women's involvement in decision making at national and international levels, "only 4 percent of signatories, 2.4 percent of chief mediators, 3.7 percent of witnesses and 9 percent of negotiators are women in the sample of 31 major peace processes between 1992 and 2011". 42

In this regard, the lack of women in decision-making levels in institution is a key challenge to their presence in formal peace-building processes. Women account for half of the population and therefore they should comprise half the decision makers. ${ }^{43}$

\footnotetext{
37 Tickner (1999)

${ }^{38}$ Baines (2005), P.4

${ }^{39}$ United Nations. Secretary General (2002)

${ }^{40}$ Ibid (2002); Baines (2005)

${ }^{41}$ Anderlini (2000); ibid (2002)

42 UN Women (2010)

${ }^{43}$ Mervis et al (2013)
} 
Feminists assert that gender equality is essential for creating a sustainable peace.

That is why, Kofi Annan, UN Secretary General highlighted that "Only if women play a full and equal part can we build the foundations for enduring peace". 44

Meanwhile, it is also assumed that issues of women could be best represented only by women so that a gender-sensitive approach would not be adopted if women are excluded from peace table. In the absence of women, their rights are not explicitly addressed and their different sufferings will not be fully understood. ${ }^{45}$ In principle, women and men are equally protected by international humanitarian norms and laws. But the practises are highly gendered and fail to protect girls and women, perpetuating inequality and violations, and hindering restoration and potentials. ${ }^{46}$

In reality, the peace table is represented by those who possess the political power that could implement or destroy peace. In the stage of bargaining, the importance of inclusiveness is put aside despite the advocacy of women organizations for peacekeeping. Very often, women's participation is challenged by the notions that the peace table is not the venue to emphasize "women's issues", and that promoting women's participatory would dissatisfy some participants and delay the peace process. Women's presence at peace table is seen as a sign of interference and, their mobilization as a direct threat to culture and traditions. ${ }^{47}$ Again, constructivist's arguments of women's aversion to violence and tendency to peace are rejected by the existing patriarchal value. Women are excluded from formal politics in maledominated societies and those who enter the political field are treated with scepticism. Some argue that women should not be involved in peace-making since they are not involved in fighting. Even some women who participated as active combatants in conflicts are excluded in the peace processes by claiming that their participation could undermine the bargaining capacity of the party they represent. ${ }^{48}$ Again, women are forced to go back to their traditional roles once the hostilities are over. Anderlini $(2004,7)$ discusses "there is a prevailing belief that peace accords are gender-neutral. There is an implicit notion that references to human rights and justice encompass everyone, including women”. In some cases, female participants are

\footnotetext{
${ }^{44}$ Kofi Anan in United Nations. Secretary General (2002), p.10

${ }^{45}$ Moser \& Clark (2001)

${ }^{46}$ McKay (2000)

${ }^{47}$ Anderlini (2000)

48 ibid
} 
pressured to withdraw by their male counterparts, who fear to share power with women after the negotiations. Male negotiators generally prioritize "peace agreement" before "gender equality". However, feminists firmly accept that these two issues must be addressed in parallel, otherwise, the issue of "gender equality" will be put aside. ${ }^{49}$ In essence, peace processes are viewed as a chance to induce women's role in politics and decision-making bodies. 50

Although there is increasing recognition for the initiatives to promote gender equality, it doesn't simply mean that there is a truly gender-equal society. Equality must ensure equal access to political, economic and social areas by all people without discrimination. 51 In this regard, feminists reject the concepts of "hierarchy, domination, the use of force or exploitation and militarism". ${ }^{52}$ Meanwhile, it is argued that the leaders and negotiators of the peace must possess the traits of openness, cooperativeness, and nurturance. ${ }^{53}$ However, women who possess these traits are marginalized from formal peace process, consequently, are also excluded from post-conflict reconstruction policies and implementation. ${ }^{54}$ Therefore, scholars have highlighted the importance of gender mainstreaming in the discourse of human security, issues of sexual violence and gender inequality in control and access to resources and decision-making.

\section{$\underline{\text { Experiences of Women and Contemporary Armed Conflicts }}$}

In the end of the Cold War, international politics is characterized by intrastate conflicts which have been instigated by racial, ethnic and religious divisions. Accordingly, these conflicts are increasingly targeting at civilian populations. More specifically, civilian women and girls are especially targeted and become the most vulnerable group in contemporary conflicts. ${ }^{55}$ Since women and men have different social roles, they are also different in vulnerabilities and experiences during conflicts and in post-conflict construction. Understanding the impacts of armed conflicts on women and girls is required for a gender mainstreaming in peace processes. According to the UN Secretary General Report, women and girl children experience

\footnotetext{
${ }^{49}$ Anderlini (2004), p. 7

${ }^{50}$ UN Women (2010), p. 12

${ }^{51}$ Pateman (1970)

${ }^{52}$ Brock-Utne (1985)

${ }^{53}$ Sterba (1994)

${ }^{54}$ Anderlini (2004), p. 7

${ }^{55}$ United Nations. Secretary General (2002)
} 
various forms of sufferings because of war. Among them, gender-based violence is the most common one and has become the strategy of war in modern conflicts. These sexual abuses include rape, sex slavery, forced prostitution, murder and other genderbased violence. 56

It is argued that power imbalance and structural inequality between women and men perpetuate the acts of violence perpetuated. ${ }^{57}$ Then, there is connection between these violence and the victim's (women's) status and sex in the society. ${ }^{58}$ Women in war experience explicit violence, implicit violence, and violence in public, institutional violence, economic violence and violence in the home. The violence experienced during war is often a growth of violence that women experienced prior to the war and is expected to further increase in the aftermath of war. ${ }^{59}$

Also, violence against women is a result of wartime gender roles. Generally, "women do not go off to fight in war and largely remain unarmed and unprotected at a time when traditional forms of moral, community and institutional safeguard have disintegrated, and weapons have proliferated, leads to women being particularly vulnerable during wartime". ${ }^{60}$ Moreover, it is incorrectly assumed in the society that "elderly women and women with children will be safe from harm and have left them to safeguard property while the rest of the families flee" ${ }^{61}$ In the lack of protection, women and girls have become easy targets of violence. Again, sexual violence committed during times of conflicts is motivated by random or systematic reasons. ${ }^{62}$ Although it is often viewed as an unfortunate outcome due to the breakdown of social and moral norms during conflicts, in reality, conflict around the world conclusively demonstrate that sexual violence is not an outcome of war, but an integral part of wartime strategy. ${ }^{63}$ More comprehensively, raping women is a physical and symbolic means of humiliating the opposing force. In many cases, women are systematically raped "as a means to exercise power over and demoralize the men in the women's family, clan and ethnic groups" and "to suppress a local

\footnotetext{
${ }^{56}$ United Nations. Secretary General (2002)

${ }^{57}$ Sideris (2001), p. 142

${ }^{58}$ World Conference \& United Nations (1996)

59 Pillay (2001), p. 35

${ }^{60}$ United Nations, Secretary General (2002), p. 14

61 Ibid.

${ }^{62}$ Ward \& Marsh (2006), p. 3

${ }^{63}$ United Nations, Secretary General (2002), p. 15
} 
rebellion". 64 Also, it is argued that rape is strongly connected with social fragmentation. Reportedly, rape is intentionally perpetrated in public, in the presence of family and compatriots with the purpose to make the whole community suffer, and sometimes lead the victims to be rejected by her community (spouse and family). ${ }^{65}$

The United Nations recognizes that the spread of Sexually Transmitted Infections (STIs), especially HIV/ AIDS is further increased by this tactical weapon of war, rape. Rape is also used as a toll for ethnic cleansing through forced pregnancy. On the other side, it is perpetrated to terminate the unborn children of the opponents through forced abortion. ${ }^{66}$ As a consequence, these various forms of sexual violence lead the victims to psychological trauma even in the post-conflict situations. ${ }^{67}$

Also, women and girls suffer from sexual slavery during conflicts. ${ }^{68}$ Most of the victims are young girls and are often victimized under the terms of military duty. According to estimation, 40 percent of child soldiers around the world are girls, and are assigned to various responsibilities including sexual services to their superiors or fellow combatants. In addition to this, they are used as forced labour during their captivity. Women are thus enslaved in more than one form. ${ }^{69}$

Moreover, it is argued that there is a link between human trafficking and armed conflicts. ${ }^{70}$ The breakdown of societal structure which follows the armed conflicts also attributes to the increase in trafficking in human beings. War makes women difficult to provide their families as well as themselves. ${ }^{71}$ In this regard, women are forced to find illegal earnings for survival and better lives. Many women have searched the help of traffickers on their own choices so that they can get rid of conflicts. In many cases, women and girls are attracted by offers of protection and access to safety zones, or purposely to work for militias in economic activities. ${ }^{72}$

Collectively, it could be argued that women disproportionately suffer from the impacts of armed conflict compared to men in the same society as a result of their

\footnotetext{
${ }^{64}$ United Nations. Secretary General (2002)

${ }^{65}$ Sideris (2001), p.147

${ }^{66}$ Ward \& Marsh (2006), p.5

${ }^{67}$ Ward \& Marsh (2006), p. 10

${ }^{68}$ Taylor (2003), p. 10

69 Ibid.

${ }^{70}$ Heyzer (2002), p. 8

${ }^{71} \mathrm{Ibid}$.

${ }^{72}$ United Nations, Secretary General (2002), p. 17
} 
status and sex, and inequality of gender roles. In addition, violence is expected to increasingly continue in the aftermath of war. Feminists believe that the increasing and continuing violence is directly concerned with the absence of women in the peace table. Despite of their unbearable sufferings, "women experiences and vulnerabilities" are still invisible and neglected in the peace table. Unless they are well-addressed, the same impunity and perpetration could not be prevented and women will remain unprotected. Feminists firmly argue that only women could fully understand the sufferings of women and could represent them at the negotiation table. As a result, feminists employ "violence against women" discourse in order to get more equal roles at the peace talks.

\section{Women's Participation in Peace Processes}

The socially constructed gender roles deter women from taking active parts in public sphere. In spite of the low levels of female participation in peace talks, feminists have continued to fight for their rights and express their concerns in peace process through parallel process. ${ }^{73}$ Peace process consists of both formal and informal activities. Women's capabilities to conduct informal peace activities which include dialogues, peace march and protests, empowerment of citizens and the promotion of intercultural tolerance are much embraced and appreciated. Nevertheless, women are seldom included in formal peace processes such as conflict resolution, negotiation, preventive diplomacy and reconciliation, since they are mostly under-represented in decision-making and military affairs. ${ }^{74}$ In other word, the social gender role in preconflict condition and during conflict has systematically excluded women from the formal peace talks.

The nature of post-conflict negotiations has allowed only men to participation since the discourse and practises are more relevant to men's experiences rather than women's. Male leaders of the conflicting parties could negotiate to end wars so that they are central player of the peace-building process. ${ }^{75}$ Again, women's exclusion could be explained by the notion that the peace table must be represented by those who have taken up arms.

\footnotetext{
${ }^{73}$ UNIFEM (2013)

${ }^{74}$ United Nations, Secretary General (2002), p. 66

${ }^{75}$ Anderlini (2000), p. 5
} 
In this matter, Sumie Nakaya (2003) points out two main arguments of feminists. It includes women's demand for equitable representation and all-inclusive peace process, arguing that half of a population is neglected if women are barred from these processes. In this regard, this demand is accepted as a reform process to ensure egalitarianism in which every citizen possesses the power of decision-making.

Secondly, it is argued that women's experience in conflict resolution could strengthen their role in peace-making because women normally approach the negotiation based on their experiences as both victims and active combatants during conflicts. ${ }^{76}$ It also suggests that peace negotiation could be interpreted more constructively, inclusively and sustainable if women's notion of social justice is considered. ${ }^{77}$ As Kofi Annan argues, women's presence is crucial not only for the inclusion of gender mainstreaming, but for the establishment of sustainable peace. Without women's equal participation, a gender dimension will never be prevailed in political structures, economic institutions and security sectors and women's concerns will also be neglected. ${ }^{78}$

Feminists argue that women could acquire new skills which are beneficial for themselves and their community and receive new opportunities for mobilization if they could participate in the peace-building processes. ${ }^{79}$ Also, they could raise their concerns and opinions, meanwhile, could use experience and knowledge they gained during conflicts.

In addition to the rejection from their male counterparts, women face many obstacles in their attempts to the formal peace processes. One of these is the lack of resources and experiences in developing effective strategies for engagement. Another hindrance is that they are less able to unite women which are divided along political lines and to strengthen gender awareness within their own communities. More importantly, women's participation, in some cases, cannot guarantee the inclusion of gender perspective and addressing women issues at the agenda of the peace table. ${ }^{80}$ It is also noted that women may not always be supporters of opportunities for other women. Some women may not agree with negotiated peace agreement due to their

\footnotetext{
${ }^{76}$ Nakaya (2003), p. 459

${ }^{77}$ Anderlini (2000), p. 6

78 United Nations, Secretary General (2002)

${ }^{79}$ Peterson (1998), p. 581; Anderlini (2000), p. 7

${ }^{80}$ UN Women (2010)
} 
political affiliation and consequently are reluctant to use such opportunities to advocate women's rights. ${ }^{81}$

\section{Adoption of Resolution 1325 and Women's participation in peace process}

"Gender equality advocates and government and civil society actors have highlighted peace processes as a strategic entry point for the implementation of resolution 1325 (2000). This imperative has been reiterated in subsequent resolutions, including 1820 (2008), 1888 (2009), 1889 (2009), 1960 (2010) and 2106 (2013)”.The Norwegian Nobel Committee's decision to award the 2011 Peace Prize to Ellen Johnson Sirleaf, Laymah Gbowee and Tawakkul Karman for their non-violent struggle for the safety of women and for women's right to full participation in peacebuilding processes confirmed the central roles of women in peace, and highlighted the strong connection between democracy, justice, and gender equality. Despite these, women's participation in peace process remains one of the most unfulfilled aspects of the women, peace and security agendas.

Soon after its adoption in 2000, the UNSCR 1325 is started to be employed by women as a tool to get conflicting parties to consider their rights in formal peace talks. However, UN Women (2010) noted that "only marginal progress has been made with regard to the number of women in formal peace process or the design and conduct of peace talks in ways that would give greater voice to women, particularly from civil society. Over the same period, a limited number of provisions addressing women's human rights have been incorporated into peace agreement. This is in spite of growing participation of women in politics and security sectors...." 82 "Genderblind peace agreements are still the norm, rather than the exception." 83 Peace talk must an event in which all aspects of peace-making are addressed. The results of peace talk are not only important for the post-war conditions, but also for the lives of both women and men in the long-term.

According to Peace Women, 54 countries (as of February 2015) have adopted national action plan for the implementation of the UNSCR 1325. However, Myanmar is not included in this list although it has the world's longest civil conflicts along with the ethnic line. Since President Thein Sein came into power in 2011, his new

\footnotetext{
${ }^{81}$ Anderlini (2000),

${ }^{82}$ UN Women (2010), p. 2

${ }^{83}$ ibid, p. 10
} 
administration launched initiatives for peace processes. However, these initiatives failed to incorporate gender perspective and to include women into the formal peace talks. Meanwhile, gender mainstreaming is also not considered by the ethnic armed groups in the negotiations with the government. There is a growing body of research looking at sexual violence against women in Myanmar conflict zones. Yet, no scholarly work is made about the lack of women in formal peace accords, connecting with tradition lack of access to the political sphere. Therefore, Myanmar's peace processes would be examined through a gender perspectives in the paper. In this regard, next chapter will introduce the civil conflicts in Myanmar in order to brief the root causes of the ethnic divide and ongoing conflicts till now. 


\section{Chapter Two: Internal Conflicts in Myanmar}

Myanmar is a country with the world's longest recorded civil war between the central government and different ethnic armed groups. The "ethnic politics" of

Myanmar is centered on how ethnic nationalities define themselves. Being an ethnically diverse society, internal conflicts in Myanmar are deeply rooted in political fractions based on differences in ethnicity. Despite of the Spirit of Pinlong that consolidated all ethnic nationalities together in gaining independence, successive governments failed to implement a "state-building" process which is essential to a heterogeneous society like Myanmar. Rather, the governments emphasized on "nation building" process through its "forced assimilation" and "Burmanization".

This chapter will analyze the internal ethnic conflicts in Myanmar. It is seven parts. The first part will briefly address colonial Burma, focusing on the British strategy of divide and rule as a main reason of the ethnic divide, and the spirit of Pinlong that consolidated all ethnic nationalities in search for independence. The second section will analyze the causes of Myanmar's ethnic conflict. The third and fourth sections will be discuss "Burmanization" under $\mathrm{U} \mathrm{Nu}$ and $\mathrm{Ne}$ Win's governments. Section five examines the military regime and ceasefire agreements and the sixth section focuses on the current reform government and the ongoing conflicts. In the final section, an overview of the internal conflicts will be discussed.

\section{Colonization, Independence Struggle and the Spirit of Pinlong}

British colonization of Burma began in 1824 and finally ousted the Burman ${ }^{84}$ King Thibaw in 1886. Pre-colonial Burma ${ }^{85}$ was never a combined Union since it was scattered as different independent kingdoms based on their geography and ethnicity, but these were later consolidated by the British. ${ }^{86}$ After that the colonial power sought to control its occupied territory through a "divide and rule strategy". They employed direct rule in central Burma through imported Indian officers and delegated the administering to the traditional leaders in the Hill Regions. Subsequently, that policy divided the country into Ministerial Burma and the Frontier Areas. ${ }^{ð /}$ The ethnic division was marked not only by the British territorial division

\footnotetext{
${ }^{84}$ In this paper, Burman refers to the majority ethnic group in Burma, and Burmese is a more contested term used to refer to all ethnic groups of Burma.

${ }^{85}$ Burma was a name used until 1989, but changed to "Myanmar" under the military government.

${ }^{86}$ Walton (2008), p. 893

${ }^{87}$ Smith (1999)
} 
but also by colonial military recruitment policies as well. The British's gradual exclusion of the ethnic Burmans and favor of Chin, Kachin and Karen ethnic nationalities in the armed forces made ethnic integration more difficult. Even the Karen troops were used to suppress Burmans' independence movement (Saya San rebellion). ${ }^{88}$ That's why, the Burmans viewed that the ethnic minorities were associated with colonial rule and the primary purpose of the British's Burmese military was to maintain internal security. ${ }^{89}$ In fact, British colonization had different impacts on the Burmans who were suppressed under direct colonial rule and other ethnic minorities who could maintain their self-determination in their own regions. Also, central Burma suffered most under the Japanese occupation since it never stretched into the mountainous regions. ${ }^{90}$ That was reflected in the independence struggles against both British and Japanese occupations ${ }^{91}$ which were mostly driven by the Burmans. Therefore, Callahan (2004) argues that the Japanese were defeated by networks of armed guerillas and soldiers fighting against the same enemy but with different objectives. ${ }^{92}$ As a consequence, the question whether or not the Frontier Areas would be associated with Ministerial Burma had become an issue when the British government was ready to grant independence to Aung San and his party, the Anti-Fascist People's Freedom League (AFPFL). ${ }^{93}$

The Pinlong Conference was a meeting that discussed about the future status of the people of the Frontier Areas after the independence. The British White Paper of 1945 stated that no decision would be made on behalf of the people of the Frontier Areas without their consent and they were placed under a "special regime under the Governor until such time as their inhabitants signify their desire for some suitable form of amalgamation of their territory with Burman proper". 94 It was suspected that the statement was released for the purpose of devastating the Burman-led independence effort. Although there was pessimism about the outcome of the Conference, the Pinlong Agreement was surprisingly approved by all of the delegates

\footnotetext{
${ }^{88}$ Walton (2008), p. 893

89 Ibid, p. 894

${ }^{90}$ Callahan (2004), p. 67

${ }^{91}$ Burma was under British rule from 1886 to 1940, then under the occupation of Japanese Fascist for five years from 1941 to 1947. Then, the British regained control of Burma in 1945 till independence in 1947.

${ }^{92}$ Callahan (2004), p. 85

93 Ibid.

${ }^{94}$ Tinker (1984), p. 262
} 
in attendance on 12 February 1947, revealing the willingness of the inhabitants of the Frontier Area to join a union of Burma ${ }^{95}$. Theoretically, the essence of the Pinlong agreement was not only to accelerate the victory of independence struggle through a unity of all ethnic people but also to build an ethnically diverse union for those who fought together for freedom from colonial power. Successively, addressing the issues of the Frontier Areas, the AFPFL continued to organize throughout Burma for the elections to the Constituent Assembly ${ }^{96}$.

\section{$\underline{\text { State Formation Conflicts, Forced Assimilation and Burmanization }}$}

The ethnic problems that confronted in Myanmar since independence in 1948 were mainly caused by "state formation conflicts" which pushed the newly independent country into civil war. ${ }^{97}$ The Pinlong's sprit, in essence, was based on "the principles of voluntary association, political equality, and the right of self-government in their respective homelands through the right of internal self-determination which they hoped to implement through a decentralized federal structure of the Union of

Burma". 98 Instead, Myanmar became "a quasi-federal union with a strong connotation of a unitary state where a single ethnic group called the Burma people controlled all state power and governing systems of a multi-ethnic plural society of the Union of Burma". 99

In addition, the government's "Burmanization" policy enforced the nation-building process thorough the acts of ethnic "forced assimilation" by successive governments of the Union of Myanmar. It originated from the colonial-period value of Burman nationalism which legitimized the significance of Burman ethnicity, language and religion (Buddhism) as a consequence of the perceived anti-colonialist sentiments. In the process of nation-building, which was implemented by using coercive force, people from different ethnic groups, whose combined homelands covered sixty percent of the territory and more than forty percent of the country's population, were left to accept forced-assimilation or to resist it by any means. In addition to constitutional crisis combined with forced assimilation, almost all ethnic nationalities

\footnotetext{
${ }^{95}$ Tinker (1984), pp. 404-05

${ }^{96}$ Sakhong (2012), p.5

97 ibid, p.1

98 ibid

$99_{\text {ibid }}$
} 
were left to choose "military means" as the sole option to resist the government's burmanization, leading to the world's longest civil conflict.

Independence is a beginning to implement nation-building and state-building process. Fukuyama (2006) argues that the process of "nation-building" establishes a community in which values are shared through rites and rituals, culture and language, collective memories and historical experiences, while "state-building" refers to the construction political institutions, common economic and legal systems in which economic development, security and well-beings of its citizens are enhanced. ${ }^{100}$ In a homogenous state, the creation of national identity based on the national characteristics is essential because the boundaries of the state or nation-sate are overlapped with the extension of an ethnic population or a single language group and where the total population of the nation-state shares a single ethnic culture. In contrast, a "state identity" is required in a plural society because it is created out of the specific characteristic of a particular "nation-state". 101

In principle, ethnic peoples could achieve their own national independence separately from Great Britain separately. However, they opted to form a Union together as a result of the Spirit of Pinlong which guaranteed self-determination and selfgovernance in a Union structure. Despite those constitutional guarantees, the successive governments of Myanmar practiced "nation-building" rather than "statebuilding", on the basic of "one ethnicity, one language and one religion" notion. ${ }^{102}$ Myanmar is multi-ethnic, multi-religious country where the state's boundaries and the nations' boundaries do not coincide so that the creation of a homogenous nation of Myanmar is hostile to multiculturalism and diversity. Consequently it caused frictions and led to the sixty-year long civil conflicts in the country.

In essence, the Pinlong sprit intended to build a state with decentralized federalism.

That's why, in the wake of the government's attempt to materialize "one nation identity" in which the values of Burma dominate and the identities of ethnic nationalities were marginalized, the Karen were the first group to demand a separate state by taking up arms, and they were later followed by other ethnic nationalities such as Chin, Kachin, Rakhine, Karah, Mon and Shan.

\footnotetext{
${ }^{100}$ Fukuyama (2006), p. 3

${ }^{101}$ Ibid.

${ }^{102}$ Flenier et al (2003), p. 198
} 


\section{Policy of State Religion, Constitutional Crisis and Ethnic Inequality}

The assassination of Aung San on July 19, 1947 was a turning point for Myanmar's politics. Based on the agreements of Pinlong Conference, Aung San's version of the

1947 Constitution promised the political autonomy and preservation of ethnic identities. ${ }^{103}$ Aung San firmly believed that "we must set up a Union with properly regulated provisions to safeguard the rights of the national minorities". ${ }^{104}$ However, $\mathrm{U} \mathrm{Nu}$ who succeeded Aung San after the assassination tried to re-draft the constitution. According to the new constitution, the power of the ethnic national state is combined with sovereign authority of the whole country. Also, representatives to the Chamber of Nationalities were to be elected based on population, whereby the domination of Burman in the Assembly was ensured. The proposed constitutional amendment was unsurprisingly unacceptable to non-Burman nationalities, who saw only Burmanization rather than the promised ethnic political equality. ${ }^{105}$

It could also be argued that the adoption of Buddhism as the state religion was the main cause of some ethnic rebellions. ${ }^{106}$ Although Aung San sought to build a secular state, $\mathrm{U} \mathrm{Nu}$ chose a more exclusive policy on religion through religious assimilation as the core of the nation-building. ${ }^{107}$ Non-Buddhist ethnic nationalities viewed the promulgation of a State Religion as further evidence of Burmanization. The Christian Kachin and Chin rebellions have been linked to that state religion bill. 108

While many ethnic nationalities took arms in response to $\mathrm{U} \mathrm{Nu}$ 's attempted Burmanization, other moderate groups reacted by constitutional means. Sao Shwe Thaike was one of the most prominent leaders opposed the state religion bill and called for the ethnic leaders to come to Taunggyi to discuss constitutional deadlocks. ${ }^{109}$ That movement was later known as the Federal Movement and asked for separation of power between the ethnic national state and the Union, and the constitutional amendment of the Camber of the Nationalities to ensure equal

\footnotetext{
${ }^{103}$ Lehman (1981), p. 51

${ }^{104}$ Aung San in Silverstein (1993)

${ }^{105}$ Sakhong (2012)

${ }^{106}$ Graver (1993), p. 56

${ }^{107}$ Sakhong (2012)

${ }^{108}$ Graver (1993)

${ }^{109}$ Nilsen (2013), p. 133
} 
representation $^{110}$. Consequently, the Federal Movement and the Taunggyi Conference collectively formed a united non-Burman initiative demanding for the power balance that was promised in the constitution of $1947 .{ }^{111}$ Also, their demands had left $\mathrm{U} \mathrm{Nu}$ with no choice rather than inviting all the political leaders to the "Federal Seminar" to address the demands from ethnic nationalities. ${ }^{112}$ But before this meeting, there was a military coup led by General Ne Win in the name of the Revolutionary Council, reasoning as an attempt to protect the national from the danger of disintegration. However, in practice, the parliamentary practice and the hope for federalism were eliminated and all the non-Burman participants of the Federal Seminar and legally elected cabinet members, including $\mathrm{U} \mathrm{Nu}$ himself were arrested. In final analysis, the failure to implement the Pinlong Agreement forced ethnic nationalities to take up arms against the central government to demand for their rights promised at Pinlong. 113

\section{Socialism, Militarization and National Language Policy}

Both $\mathrm{U} \mathrm{Nu}$ and $\mathrm{Ne}$ Win employed "nationalism" in the notion of "one ethnicity, one language and one religion" in materializing the nation-building process. $\mathrm{U} \mathrm{Nu}$ mixed nationalism with Buddhism, but $\mathrm{Ne}$ Win mixed nationalism with Socialism, combining with the military leadership. His army named "Tatmadaw" deployed "four cut strategy" in combating ethnic insurgencies across the country, cutting food, financial resources, information and insurgent's heads. ${ }^{114}$ In that regard, Ne Win's "national language policy" was mainly designed to cut information off in ethnic areas. That policy, on the one hand, prohibited the publication of any information in ethnic languages so that systematically eliminated and even destroyed ethnic identities. ${ }^{115}$ Also, the promulgation of the 1962 Printers and Publishers Registration Law and the 1965 Censor Law blocked the publications of ethnic language. Even the secular and religious schools' curriculum and teaching materials were prohibited if they were written in ethnic language. On the other hand, state mechanisms, such as declaring Myanmar language as medium for all level of teachings, was used to

\footnotetext{
${ }^{110}$ Taunggyi Conference (1961)

${ }^{111}$ Silverstein (1989), p. 81

112 Lehman (1981), p. 53

${ }^{113}$ Sakhong (2012)

${ }^{114}$ Maung Aung Myoe (2009), p. 26

${ }^{115}$ Sakhong (2010), p. 193
} 
widespread the dominance of Myanmar language. ${ }^{116}$ More importantly, the 1974 Constitution adopted Myanmar as the official language. According to the new 1974 Constitution's Article 198, ethnic languages could be used only for communication purposes, but they were not well-preserved. Consequently, distinctive characteristics of ethnic people including different cultures, language and religion were threatened to survive because their languages were made legally unofficial. ${ }^{117}$ In the denial of the fundamental rights, almost all ethnic nationalities, by the time of the formulation of the new constitution in 1974, had already transformed into insurgent groups to fight against the dictatorship. The most effective reaction could be seen in their formulation of the "Federal National Democratic Front"118 in 1975, collecting all non-Burman ethnic nationalities exclusively with the purposes of the establishment of a genuine federal union. ${ }^{119}$

Although it was successful in dealing with Communist insurgents (Burmese Communist Party), the "four cuts strategy" of the military (the Tatmadaw) was ineffective in the ethnic regions. Smith (2007) argues that ethnic armed groups, most notably, the Karean National Union (KNU), Kachin Independence Organization (KIO) and the Shan State Army (SSA) could maintain their controlled areas and launch counter-attacks against the Tatmadaw using conventional and guerrilla warfare. In addition, ethnic insurgencies were argued to be prolonged and financially supported by the black market taxation. ${ }^{120}$ Myanmar's economy was unstable and under-developed due to the centralized economic structure, government's mismanagement, international isolationism and reliance on the black market for its consumer goods which illegally imported from neighboring countries across the ethnic groups-controlled borders. Ne Win's announcement of the demonetization of the country's three highest banknotes in 1987 was aimed at "insurgent and black marketers". 121 However, ethnic armed groups kept most of their funds in foreign currencies were not affected. Instead, ordinary people suffered most since they lost their savings. It was reported that sixty to eighty percent of all the money in circulation in Myanmar became worthless in one sweep. The demonetization

\footnotetext{
${ }^{116}$ Sakhong (2012), p. 8

117 Ibid.

${ }^{118}$ FNDF was later transformed into "the National Democratic Front (NDF)" in 1976.

${ }^{119}$ Khaing. S. N. Aung (2000), pp. 78-9

${ }^{120}$ Smith (2007), p. 36

${ }^{121}$ Lintner (1999), p. 338
} 
combined with general dissatisfaction of the public with socialism, led to prodemocracy demonstrations led by students in $1988 .{ }^{122}$ The demonstrators were gunned down and brutally crushed down by the Tatmadaw which later seized power.

Ne Win's "Burmese Way to Socialism", and the policy of Burmanization through militarization and a national language policy only further exacerbated ethnic divisions, something that remains unsolved even today.

\section{The Military Regime and the Ethnic Politics}

Since August 1988 uprising, international attention had focused on the regime's brutal repression of civil liberties, human rights violation and the authoritarian rule, but less emphasized on the ethnic issues. Some ethnic minorities became open to negotiation with the regime once foreign funding dried up. ${ }^{123}$ The regime's political objective was the defeat of all opposition through the military. In this regard, the Tatmadaw was shaped as the only patriotic institution that was capable of materializing the so-called "national reconciliation" which was failed by the parliamentary system in the years after independence and the Burmese Way to Socialism since 1960s. ${ }^{124}$

Prior to 2010, the military Regime (State Peace and Development Council SPDC) could reach ceasefire agreements with a total of 40 ethnic armed groups. ${ }^{125}$ General Khin Nyunt ${ }^{126}$ was the driving force behind the ceasefires in which the ethnic armed groups were allowed to keep their arms and territory until a new constitution had been put together and to re-enter politics. In addition to those political promises, economic opportunities such as exploitation of the natural resources in their areas and other "new economic complexes" were also offered in exchange. The regime also supported health care and educational service as well as infrastructure development. The military regime presented those ceasefire agreements as parts of its successful policy of "national reconciliation" which was the most defining characteristic of the military rule. ${ }^{127}$ To some extent, the ceasefires guaranteed the physical security, economic development and social welfare of the locals living in

\footnotetext{
${ }^{122}$ Lintner (1999), p. 338

${ }^{123}$ Ganesan \& Hlaing (2007), p. 220

${ }^{124}$ Selth (2002), p. 37

${ }^{125}$ Min Zaw Oo (2014), p. 8

${ }^{126}$ Khin Nyunt was the chief of Military Intellience (MI) which was the only institution for peace processes in Myanmar under the SPDC.

${ }^{127}$ Hlaing, Taylor \& Than (2005)
} 
the previously conflict areas. It allowed the operation of some Civil Society Organizations and NGOs in those areas to promote the health and educational sector. In addition, all ceasefires groups were encouraged to be represented at the controlled National Convention that re-opened in $2004^{128}$

The primary demands of the ethnic delegates representing the ceasefire groups included increased legislative and administrative power for local governments, the formation of local ethnic security forces and a federal union of Burma. ${ }^{129}$ Their demands of "popular sovereignty, bicameral legislature, equal representation at Chamber of Nationalities, State Assembly, State Government and State Supreme Court, and Multi-party Democracy" were met in the 2008 constitution. ${ }^{130}$ Although, the most important and long term challenges such as "equality, self-determination and constitutional rights for ethnic nationalities, Democracy, Human Rights and Gender Equality" were still neglected. ${ }^{131}$ Although the 2008 Constitution grants each region and state its own government, the Constitution also gives the President power to appoint the chief minister. Also, 25 percent of reserved parliamentarian seats for the military and the military's nomination for the Misters for Home Affairs, Defense Services and Border affairs still increase suspicions. In addition, ethnic minorities felt that the country's new prescribed "flag" symbolized their exclusion from the mainstream of the country since only the dominated Burman group was represented by one star although the stars on the old flag represented the main ethnic nationalities in the country. ${ }^{132}$

Moreover, tensions were intensified when all ethnic armed forces were forced to transform into the Border Guard Forces under the central command of the Tatmadaw prior to the 2010 elections. Many critics argued that the BGF plan was simply the regime's attempt to make the ethnic armed groups to give up their weapons. In this sense, only two of major ceasefire groups - the Democratic Karen Buddhist Army (DKBA) and the National Democratic Army-Kachin (NDAK) - agreed.

But the Kachin Independence Army (KIA) and the United Wa State Army (UWSA) refused the BGF plan because they accepted that they need to keep weapons as their

\footnotetext{
${ }^{128}$ Lall (2009), p. 10

${ }^{129}$ Ibid, p. 11

${ }^{130}$ Sakhong (2012)

${ }^{131}$ Sakhong (2012)

${ }^{132}$ Chaturvedi (2012)
} 
last source of leverage in their long-run battle for autonomy and prepared for military defense. ${ }^{133}$ The regime also set up its economic and military pressures on militia groups resisting its plan. It included the blockage of the Chinese border trade to cut the income source of the KIA, the offensive attack on the small Kokang militia group (MNDAA) and the capture of their bases in Shan State in 2009. Also, the regime ignored the KIO's request to stop Chinese-operated hydroelectric dam projects in Kachin state. Upon its denial, the KIO destroyed a number of bridges and clashes between the two armies broke out. ${ }^{134}$ In general analysis, despite the relative peacefulness that followed the ceasefires of the 1990s, it could be pointed out that the 2008 constitution, the regime's BGF plan and the continued militarization failed to build trust of the ethnic armed groups, leading to the resumed hostilities in some ethnic areas.

\section{The Reform Government and the Ongoing Ethnic Conflicts}

Myanmar cannot build regional peace and stability with its bordering countries unless ethnic political problems are first solved. Realizing the necessity for "political solution" to deal with the country's long term ethnic dilemma, President Thein Sein's government instantly initiated progressive political changes once after assuming power. ${ }^{135}$ It is less possible for Myanmar to engage in pursuing and implementing development unless genuine internal peace and regional stability becomes a reality. Being aware of the political, economic and social problems that the country is facing due to political instabilities, President Thein Sein was the one who made the first move by initiating unprecedented political reform in the country. One of his guiding three basic principles for political change was "permanent peace", inviting ethnic armed groups to ceasefire agreements and political dialogues at the peace table. These initiatives are much praised by international community. However, it is also believed that the 2008 constitution was a political strategy masterminded by Senior General Than Shwe for his future retirement. Accordingly, power is not vested in one place, but divided and distributed to four branches of the state apparatus: namely the Executive, the Legislature, the Tatmadaw (Armed Forces) and the Union Solidarity and Development Party (USDP) ${ }^{136}$. In this respect, a civilian President cannot

\footnotetext{
${ }^{133}$ Min Zaw Oo (2014), pp. 11-3

${ }^{134}$ Myanmar Peace Monitor, "BGF and resumption of conflict".

${ }^{135}$ Sakhong (2012)

${ }^{136}$ USDP is a ruling party, which is supported and backed by the military.
} 
directly manage or administer the affairs of the military, nor has he the power to give commands to the army.

Following the President's negotiation with the democratic forces, the second move was the proposal of peace talks and ceasefire agreements with ethnic armed groups. But as noted, the President is powerless in military affairs so that increased militarization in some ethnic regions has undermined the attempted peace talks by the new government. More notably, Sakhong (2012) also point out the correlation between the military dictatorship and civil conflicts. It has been argued that the civil war and ethnic conflicts were intentionally cultivated and nurtured by the successive regimes in order to build military dictatorship. ${ }^{137}$ Instead of solving these dilemmas by political means and political dialogues, successive regimes since 1962 have consistently used military means as a policy against the ethnic nationalities. Internal conflict has been used as an excuse to justify a military dictatorship that can only survive with prolonged internal conflicts. It seems that this argument is more convincing since the current situation has witnessed the increasing militarization. Even in the middle of ongoing peace talks, conflicts and fighting are resuming in ethnic areas due to the offensive attacks launched by the Tatmadaw. Currently, fighting is ongoing in Kachin, Kayin and Shan States, undermining the Government's attempt to build a sustainable peace.

Different groups have been at war with the Tatmadaw for different lengths of time, but this has never led to the risk of national disintegration. Indeed, it could be assumed that the ethnic nationalities were the victims of power struggle among

APFPL leaders since the electoral victory had been prioritized. U Nu's "policy of state religion" was indeed aimed at attracting supports from Buddhist ethnic nationalities who composed of majority of the country's population, rather than suppressing non-Buddhist ethnic groups. ${ }^{138}$ Furthermore, the act of "Burmanization" could be explained by the facts that Burman were the majority of the total population and they contributed as the main drive of the independence struggle so that the postcolonial power structure was undeniably dominated by Burmans.

\footnotetext{
${ }^{137}$ Sakhong (2012), p. 4

${ }^{138}$ Among eight main ethnic races, Burman, Mon, Rakhine and Shan are mostly Buddhists and composed of approximately 80 percent of the total population.
} 
The civil conflicts in Myanmar were not rooted in economic grievance, but mainly associated with political causes. However, those deadlocks were never solved by political means, the only solution to the problem. Instead, they were prolonged by a policy of militarization by successive governments. Military leaders intentionally extended the internal conflicts as an excuse to construct the military dictatorship and maintain their power.

To resolve these ethnic issues, it is important to address the issue of autonomy for the ethnic nationalities. Positive developments by the current civilian government have brought hope that a second Pinlong-like Conference might be convened where all ethnic groups are included and given the status of stakeholders. Ethnic armed groups have been offered greater economic and social development opportunities in exchange for giving up arms. However, the exact content and nature of the peace negotiations are still unclear. Meanwhile, conflicts have devastating impacts on the whole community, particularly on women and girls. Therefore, the experiences and vulnerabilities of women during conflicts of Myanmar will be examined in the next chapter in order to understand the different impacts of conflicts on women and men. 


\section{Chapter Three: Impacts of Armed Conflicts on Women and Girls}

Armed conflicts are not gender-neutral, meaning that they have different impacts on women, girls, men and boys. Gender inequalities are further exacerbated during periods of armed conflicts, and this continues during post-conflict reconstruction. Conflicts create further workloads for women and girls in addition to their traditional gender roles. During conflicts, women become targeted for sexual violence because of their status in the society. In addition, conditions of the conflicts force women and girls to engage into forced labor, trafficking, migrating, and other forms of exploitation because of their vulnerabilities to abuses, difficulties in access to basic needs such as health care and education, and adverse situation for their survival. In general, it could be said that conflicts have more devastating impacts on women and girls. This chapter seeks to examine the impacts of armed conflicts in Myanmar on women and girls in ethnic conflict areas during and after armed conflicts.

\section{Threats to personal safety and Socio-economic dimensions}

Armed conflicts impose different risks and dangers on civilian women and girls in comparison with civilian men and boys. According to different gender roles prescribed by the society, women have generally not been recruited for fighting. Therefore, they largely remain unarmed and unprotected in the wake of armed conflicts when traditional forms of safeguards have collapsed and weapons have proliferated. ${ }^{139}$ In addition, social stereotypes wrongly assume that elderly women and women with children are safe from harm so that they are left behind to protect property while other flees. ${ }^{140}$ The Kachin Women Association Thailand (KWAT) has documented a case where a 48 -year-old Kachin woman, left alone in a church after most of the other villagers had fled, was gang-raped by a patrol of Burmese troops. ${ }^{141}$

Furthermore, their prescribed gender responsibilities including the collection of food, firewood and water also impose women and girls at risks of dangers such as kidnapping, sexual abuse and exposure to landmines. ${ }^{142}$ According to research by the the Shan Women's Network 14 percent of rape incidents in one conflict area were

\footnotetext{
139 Lindsey (2004), p.20

140 Lindsey (2001), p. 44

${ }^{141}$ Women League of Burma (2014), p.8

${ }^{142}$ Ibid, p.44
} 
villagers who were caught by troops in or near their old villages in search for food, firewood and water. Those women were accused of being wives of insurgents, or providing food to insurgents. ${ }^{143}$

Conflicts make women and girls more vulnerable by reinforcing their social roles in addition to existing traditional responsibilities. Most men in conflict areas are used as forced labour by both the Myanmar army and the NSAGs. Therefore, men are usually the groups that leave the family in the wake of armed conflicts. This leaves women solely responsible for all family responsibilities, which include raising children, earning money, housework and caring for elderly relatives. ${ }^{144}$ During conflicts when their male family members are imprisoned, killed or leave to join resistance movements, women are forced to take dual responsibilities as homemakers and primary earners. In the absence of a male breadwinner for family survival, women migrate or separate from their children to find work, and engage into informal labor market where only low skill and under-paid jobs are offered. ${ }^{145}$ In a situation when their male relatives have fled, gone to exile, joined fighting forces or have died or disappeared, the number of female-headed household in the conflict areas are is disproportionately high. ${ }^{146}$ Consequently, women become stressed with workload and physical and mental illness. ${ }^{147}$

In the collapse of livelihood systems due to conflicts, women and girls have to adjust their traditional roles for survival. In the case of Myanmar, most women often choose or are forced to leave their home communities in search for works. According to the results of the National Census in 2014, the population of women is more than that of men in the whole country except in the Kachin and Kayah states. ${ }^{148}$ Daw Doi Bu, a Kachin parliamentarian, points out that migration of women to neighboring countries because of the insecurity and threats during conflict times is the main reason. ${ }^{149}$ However, many of them survive as undocumented illegal migrant workers and have to work in low-wage and exploitative industries where working conditions are

\footnotetext{
${ }^{143}$ Shan Women's Action Network (2012), p.26

${ }^{144}$ Women League of Burma (2000), p.18

${ }^{145}$ Kumari (2012), p.4

${ }^{146}$ O'Shannassy (2000), p.16

${ }^{147}$ Women League of Burma (2000), p.18

${ }^{148}$ Ministry of Immigration and Population (2014), p.4

149 Interview with Daw Doi Bu (26-11-2014) in Nay Pyi Taw
} 
extremely bad and full of abuses, and where they are at higher risk of trafficking to third countries. 150

In Myanmar, there is a strong connection between conflict and narcotic production since the drugs trade is the main source of revenue for conflict actors to survive. ${ }^{151}$

As a result, the number of drug users is increasing, putting the burden of social problems on women in addition their existing problems.

\section{Violence against Women and Girls}

During times of armed conflicts, women and girls experience all forms of violence, especially sexual violence. In Myanmar, women and girls in the ethnic conflict areas are specifically targeted for systematic sexual violence by the military, the police and border guards as an anti-insurgence tactics against the ethnic minorities. ${ }^{152}$ Very often, sexual violence against ethnic women and girls are perpetrated by military commanders with full impunity. ${ }^{153}$ Rape has been practiced as a signal of its power on ethnic people by the Myanmar army, demoralizing ethnic communities by terrifying the potential victims because raping of women would leave the entire community to feel unable to protect their women and girls. Rape was used by the military regime to establish their dominance over those parts of the ethnic population who refuse to capitulate and enter the fold. ${ }^{154}$

In addition, rape is a way to change ethnic balance in Myanmar. Ethnic nationalities view that "Burmanization" is applied through the acts of rape and forced marriage and/ or pregnancy. In this view, the regime soldiers intentionally try to impregnate ethnic women. Rape victims are forced bear 'Burman babies', but are prevented from bearing children whose father is from ethnic groups, increasing the Burman majority population. ${ }^{155}$ There are reports that soldiers are offered monetary rewards and improved chances of promotion if they can marry certain kinds of ethnic women. ${ }^{156}$ Rape is not a single random act committed against unlucky individuals, threatening

\footnotetext{
${ }^{150} \operatorname{Min}(2000)$, p. 15

151 Jelsma \& Kramer (2012)

${ }^{152}$ Shan Women's Action Network (2012)

${ }^{153}$ Women League of Burma (2004)

${ }^{154}$ Women League of Burma (2000), p.30

${ }^{155}$ Apple (1998), p. 24

${ }^{156}$ Ibid, p.60
} 
the entire community with full of traumatized people. Although some cases are reported to the army for justice, the regime denied acknowledging and punishing the perpetrators. Local human rights and women's groups have documented reports of sexual violence by the Myanmar army, but the same pattern of impunity continues unchecked. WLB and its member organizations have documented over 100 rape cases perpetrated by the Myanmar army since 2010, and linked these perpetrations with military offensive attacks in Kachin and Northern Shan States since 2011. ${ }^{157}$ Also, the victims of sexual violence also face with serious health and social problems. The victim-blaming and the rejection of family member could lead to feelings of shame, guilt, loneliness, worthless, powerless and denial and cause damages to women's social and mental well-beings. In some societies, the victims who acknowledged that they were raped were out-casted by husbands and family members, leading to ostracism and isolation.

The conflict victimization of women for sexual violence also brings various negative outcomes which includes, psychological problems such as victim-blaming or isolation; increased risks to HIV and other STIs; and perceived normalization of violence against women. ${ }^{158}$ It is important for victims to receive support and understanding from families and communities without blaming her. However, in most of the cases, the victims who confessed that they were raped are shunned by their husbands and family members, leading to ostracism and isolation. ${ }^{159}$

\section{Health of women and girls}

Like men and boys, women and girls are also wounded and killed in armed conflict. But in addition, biological differences also impose extra health threats. Because of their sexual and reproductive roles in the society, their physical vulnerabilities are higher than men's and are further exacerbated during conflicts.

In times of famine and food shortage, women are more prone to malnutrition than men because of their unequal access to food sources. As a result of long conflict and existing poverty, scarcity of basic needs is common in Myanmar, especially in ethnic areas. This situation even leads to chronic malnutrition, starvation and illness by the

\footnotetext{
${ }^{157}$ Women League of Burma (2014)

${ }^{158}$ Falb et al, (2013), pp.279-283.

${ }^{159}$ Shan Women's Action Network (2012)
} 
regime's Forced relocation, the "Four Cuts 160 ", strategy and its mismanaged development projects. ${ }^{161}$ As a male-dominated society, food distribution prioritizes males at the expense of women and girls. Furthermore, women's specific reproductive roles are affected by the overall decline in basic health care. ${ }^{162}$ Mothers in conflict areas cannot receive sufficient health care although they require nutritional and physical care. The combination of a lack of health care facilities and presence of armed conflict, means maternal and infant mortality and morbidity is higher for women in rural and conflict areas. ${ }^{163}$ The problems of miscarriage, repeated pregnancy, unwanted pregnancy, sterilization, unsafe abortion and untested traditional medicine are very common due to the lack of access of family planning. Having many children keep poor families in the cycle of poverty, and access to education and health care are also limited. In these situations, women and girls are the ones who sacrifice for the sake of family. ${ }^{164}$ Another serious matter of conflicts is landmines, which put additional burden on women through widowhood.

\section{Women and girls as Refugees and Internally Displaced Persons}

In both refugee and IDP camps, women and girls can be at risk of human rights abuses due to the weakness of existing community and family protection mechanisms. These women are subjected to physical and sexual attacks, rape, domestic violence and sexual harassment. Women who are living as refugees and IDPS also experience sexual violence at higher rates too. Sexual violence against women in Thailand from Myanmar is opportunistic due to their illegal status. Also, it is difficult to charge the rapists because impunity is safeguarded by existing deeply rooted systems of social patronage. ${ }^{165}$ Likewise, language barriers, different social backgrounds and their distinct appearance also make refugee women from Myanmar in India more vulnerable to sexual abuse. ${ }^{166}$ Refugee women in India continue to face

\footnotetext{
${ }^{160}$ The "Four Cuts" military strategy employed by the SPDC is aimed at insurgency groups by targeting civilian populations. It aimed to cut food, ammunition, recruits and information from insurgency groups operating in a particularly area by for forcibly relocating all people living in that area to an SPDC controlled relocation site, usually near a big town, road or military barracks.

${ }^{161}$ Women League of Burma (2009), p.4

162 Plümper \& Eric Neumayer (2006), pp.723-754.

${ }^{163}$ Women League of Burma (2000), p.21

${ }^{164} \mathrm{Ibid}, 2000$, p.21-29

${ }^{165}$ Falb et al, (2013), pp.279-283.

${ }^{166}$ Kumari (2012), p.8
} 
domestic violence because men believe they have the right to beat women at any time if they don't obey. ${ }^{167}$

In conclusion, the impact of decades of military repression on the population of Myanmar has been devastating. Women and girls in the conflicts areas have suffered disproportionately since they are oppressed based on both their ethnicity and gender. Also, women have had to bear the additional social burden as a consequence of armed conflicts. The combination of increased militarization and gender-based discrimination or violence has made women and girls more vulnerable. Therefore, Myanmar's armed conflicts are not gender-neutral - they have different impacts on women and men.

Peace is the most important prerequisite to gender equality. That is why peace processes must to be sensitive to the specific needs of women during conflicts and in their aftermath. Women have specific capabilities and skills to contribute to recovery, to build and sustain peace. Accordingly, it is essential for women to be included in both formal and informal peace processes in order to represent the voice of the most vulnerable groups. However, as we will see in the next chapter women's participation in the current peace talks of Myanmar is minimal.

167 Kumari (2012), p.7 


\section{Chapter Four: Peace Processes in Myanmar}

Since taking power in 2011, Thein Sein's government has initiated a "new peace process" which has been prioritized as a fundamental part of the country's political reforms. However, Myanmar remains a land in political and ethnic crisis. Although the new peace approach has led to ceasefire agreements with many armed groups, ethnic division and political divisions are still emerging in national politics and threatening the country's democratic transition and national reconciliation. In reality, these ceasefire deals are still fragile because of increased militarization in many ethnic areas. This chapter provides an overview of attempts to forge peace deals under the military and the new civilian governments. It also seeks to identify the key challenges to peace and those perspectives that are missing in the peace process.

\section{Peace Process under the Military Government}

Since the outbreak of conflict in 1948, successive governments have pursued a range of peace initiatives. Prior to 1988, under the leadership of the Burmese Socialist Programme Party (BSPP) ${ }^{168}$, ceasefires broke down within short periods. ${ }^{169}$ Starting from the early 1990s, however, a new initiative for peace was launched by the State Law Order Restoration Council (SLORC) ${ }^{170}$ which replaced the BSPP, introducing an ethnic-ceasefire policy which promised the building of a multi-ethnic, multi-party democracy. ${ }^{171}$ In those initiatives, the Military Intelligence (MI) was the key institution that facilitated the relationship between the government and the ceasefire groups. As a mandated institution of the SLORC to implement the peace process, the MI negotiated with ethnic Non-State Armed Groups (NSAGs) one after another. ${ }^{172}$ Consequently, by 2005 the regime had reached ceasefire deals with a total of 15 NSAGs. ${ }^{173}$ Though those ceasefire deals were based on an informal understanding or

\footnotetext{
168 BSPP was formed by the Ne Win's military regime after the military coup I 1963 and was the sole political party allowed to exist legally in Myanmar during the period of military rule from 1964 to 1988 when it is dismissed as a result of popular uprising.

${ }^{169}$ Min Zaw Oo (2014), p-8

${ }^{170}$ SLORC was a military regime later known as the State Peace and Development Council (SPDC) which replaced the BSPP after the military cracked down against the nationwide mass uprising in

September 1988.

${ }^{171}$ Kramer 2009, pg-11-3

${ }^{172} \mathrm{Ibid}$

${ }^{173}$ Irrawady, "Lists of ceasefire deals with the junta" http://www2.irrawaddy.org/research show.php?art id=444
} 
a "gentleman's agreement" since the regime did not officially sign any ceasefire agreements ${ }^{174}$ except in the case of the Kachin Independent Organization (KIO). ${ }^{175}$

Details of those agreements were never made public, but it seems that larger groups were in a relatively strong position and groups that reached earlier agreements were offered better deals which included autonomous control of territory (called special regions), promises of government assistance in developing areas and, in some cases, material support and business concessions. ${ }^{176}$ Most of the larger ceasefire groups were allowed to retain their arms and granted extensive area of territorial control so that they could function as de facto local administrations. ${ }^{177}$ Following the ceasefires, NSAGs were given business opportunities and special privileges in the areas such as natural resource extraction, transportation and export \& import industries. In return, those verbal agreements restricted them from recruiting and expanding armament, and discussing political settlements with the regime which was characterised merely as a "transnational government". It was agreed that a political settlement would be discussed appropriately under the next government. ${ }^{178}$

Myanmar's internal conflicts were driven by a mixture of socio-political grievances and deeply-rooted economic agendas. ${ }^{179}$ Therefore, economic incentives alone would not solve the country's six-decade long political impasse of the country without addressing the related vulnerabilities of the affected communities. More importantly, ceasefires in most cases did not bring any socio-economic progress to the ethnic communities as those who reached agreements with the government and received the business incentives did not represent the whole ethnic population. Resolving the ethnic conflict needs to go beyond an end to armed confrontations. Genuine democracy must guarantee the rights of all ethnic nationalities and their selfdetermination. ${ }^{180}$ In this regard, federalism is accepted to be fundamental to any

\footnotetext{
${ }^{174}$ Kuppuswamy, (2011)

${ }^{175}$ Min Zaw Oo (2014)

${ }^{176}$ South (2003)

${ }^{177}$ South (2012) pg-22

${ }^{178}$ Kramer 2009, pg-15

${ }^{179}$ South 2012, pg-21

${ }^{180}$ Interview with Daw Phyu Phyu Thin (25 November 2014) in Nay Pyi Taw
} 
resolution of ethnic conflict among different stakeholders, especially by ethnic leaders. ${ }^{181}$

From 1989 to 2010, all ceasefires were just security agreements, not political settlements. Also, those ceasefire deals were applied without clear codes of conduct applicable to both negotiating parties. ${ }^{182}$ Generally, Myanmar's ceasefire deals under the regime were relatively stable apart from a few violation incidents. In other words, the ceasefire in Myanmar during that period was regarded as the longest record of

"negative peace" 183 in any modern intra-state conflicts. Both sides preferred to focus on military matters and economic opportunities. Notably, business interests were the main incentive for the NSAGs to maintain ceasefire with the regime. Since ethnic leaders prioritized business opportunities, they frequently failed to address the importance of a political solution with the regime. In the absence of political settlements, the sustainability of the peace was undermined. ${ }^{184}$

Ceasefires under the SLORC were achieved through bilateral frameworks with individual armed groups since the regime refused to negotiate with a coalition of groups collectively. Therefore, the regime was accused of employing "divide and rule" tactics in order to undermine the bargaining position of the NSAGs. ${ }^{185}$ On the other hand, divisions among the different NSAGs also made a single ethnic alliance impossible. Despite of the formation of groupings such as the National Democratic Front (NDF) and the Democratic Alliance of Burma (DAB) in the 1990s, power struggles among them resulted in collapse of the alliances and their later individual negotiation with the regime. ${ }^{186}$ Fractional politics always prevented the NSAGs in Myanmar from solidifying their more cohesive and effective alliance position in negotiation with the regime.

\footnotetext{
${ }^{181}$ Interview with Dr Than Ngwe Thin $(25$ November 2014) in Nay Pyi Taw

${ }^{182}$ Min Zaw Oo (2014), p-10

${ }^{183}$ Johan Galtung defined negative peace as a condition where physical violence may be absent but political oppression still persists (Galtung (1964), pp. 1-4

${ }^{184}$ International Crisis Group (2011), p. 4

${ }^{185}$ Interview with a military representative of Yangon Divisional Parliament

${ }^{186}$ Min Zaw Oo (2014), p.9
} 
In 2005, the dynamic of ceasefire shifted following the purge of Gen. Khin Nyunt and his associates, and the dismantling of the MI apparatus. ${ }^{187}$ This move had a serious impact on the ceasefires because Khin Nyunt was the key player behind them and the only military leader who could develop a personal relationship and built mutual-trust with many of the leaders of the ceasefire groups. In addition, all direct contact with the ceasefire groups was controlled by his MI.

Relations between the government and the ceasefire groups deteriorated because of growing government pressure, arrest of ethnic leaders ${ }^{188}$ and the use of force to press groups to disarm. ${ }^{189}$ Although another military institution, Military Security Affairs (MSA), replaced the MI and tried to deal with the ceasefire groups, the newcomers could not restore confidence and friendship to the previous level. That is why the period from 2006 to 2010 saw high level of uncertainties on both sides. Growing distrust and concern led some armed groups to accelerate recruitment and rearmament. $^{190}$

In addition, distrust on the part of the ceasefire groups was escalated by the introduction of the new constitution in 2008, which ordered them to transform into the Border Guard Force (BGF) under the management of the Tatmadaw or become constitutionally illegal. The regime reasoned that the BGF plan was the only way to adjust between the constitutional demand and the stance of ethnic armed groups to maintain their weapons while the total disarmament and the fully integration into the Tatmadaw were impossible. ${ }^{191}$ For smaller ceasefire groups, the government's BGF offer was acceptable. However, larger groups with a stronger political agenda refused, believing that the plan was intended to undermine the command and control of the ethnic armies. Only 5 out of 25 groups that reached ceasefires with the regime by 2009 agreed to put themselves under the BGF plan and 15 changed themselves into the People's Militia. Five organizations refused to transform into either BGF or

\footnotetext{
${ }^{187}$ The Military Intelligence (MI) was led by Gen. Khin Nyunt who the armed rebel groups considered moderate. In October 2005, Gen. Khin Nyunt and his associates were removed from power as a result of intra-fractional conflict within the military regime.

${ }^{188}$ In Feburary 2005, Hso Ten from SSA-North and SNLD leaders Hkun Htun Oo and Sai Nyunt Lwin were arrested while attending a meeting in Taunggyi and subsequently sentenced to long jail terms.

${ }^{189}$ Kramer (2009), p. 34

${ }^{190}$ Min Zaw Oo (2014), p. 11

${ }^{191}$ International Crisis Group (2011), pp. 4-5
} 
militia. ${ }^{192}$ Among them, the Kachin Independence Organization (KIO) was the only group which resumed an open conflict with the military starting in 2011. Overall, it the junta's ceasefire process was successful at least to some extent. However, many of the agreements failed to address the root causes of conflict or to produce a political solution and so a sustainable peace remained elusive.

\section{Understanding the Current Peace Process in Myanmar}

Legitimacy is the key challenge for the new government led by ex-military leader Thein Sein. Increasing the government's domestic and international legitimacy was critically important for the new administration, so it launched a series of reform initiatives to implement democratization and national reconciliation. ${ }^{193}$ Those attempts were much welcomed and appraised by the international community. However, the current reform pattern was just perceived as liberalization, rather than a complete democratic transition. In essence, the building of a democratic society would not be achieved without resolving the country's long ethnic dilemma. In this regard, the "peace process" became a fundamental part of the reforms driven by the new government of Myanmar.

In his inaugural speech on 30 March 2011, President Thein Sein stated that building national unity was his top priority, mentioning the decades of armed conflicts with the ethnic nationalities caused by dogmatism, sectarian strife and racism. ${ }^{194}$ On 18 August 2011, the new government made an offer to all armed groups to engage in a peace process. That reconciliatory gesture was the first official overture made nationwide since $1963 .{ }^{195}$ It was also announced that the peace talks would have three steps which included state-level ceasefire talks, national level talks and political dialogue. ${ }^{196}$ The National Parliament established the National Races Affairs and Internal Peace Making Committee which was headed by USDP members of parliament ex-generals U Thein Zaw and U Aung Thaung. That committee mainly dealt with the groups which had previously agreed to ceasefires with the government

\footnotetext{
192 Five groups that refused the BGF plan were the Kachin Independent Organization (KIO), the New Mon State Party (NMSP), the United Wa State Army (UWSA), the Karen Peace Council (KPC), and the National Democratic Alliance Army (also known as Meila Special Region 4).

${ }^{193}$ Yawnghwe (2013), pp. 44-9

${ }^{194}$ New Light of Myanmar (1-4-2011)

${ }^{195}$ Sakhong in Min Zaw Oo (2014)

${ }^{196}$ Burma Partnership (2012)
} 
under the junta. ${ }^{197}$ A second team was led by Minister U Aung Min, with the aim of developing agreements with groups that had previously refused to have a ceasefire. Both teams achieved early success and reached ceasefire deals with 14 NSAGs within one year. More importantly, the United Wa State Army (UWSA), the largest ethnic armed group in Myanmar, and the Nationalities Democratic Alliance Army (NDAA) were the first groups that joined the new peace process in September 2011. Both were among the five groups that remained outside the previous ceasefire process. Two other major groups, the Restoration Council of Shan State (RCSS) and the Karen National Union (KNU), signed ceasefire agreement in December 2011 and January 2012, respectively. ${ }^{198}$ Those earlier successes accelerated the peace process, encouraging other groups to engage in the new round of ceasefires.

Based on their previous experience, the NSAGs were suspicious of Thein Sein's government's willingness to establish a genuine peace that ensured self-determination and equality for ethnic minorities. Also, they understood the need for a political solution to develop a federal system. In this regard, they realized that they could not alone force the government to agree an acceptable solution. Therefore, the United Nationalities Federal Council (UNFC) was formed in 2011 as a coalition of ethnic armed organization in dealing with the government during peace negotiations. ${ }^{199}$ Currently, the UNFC supported the ethnic armed groups' Nationwide

Ceasefire Coordination Team (NCCT) in establishing policies for a nationwide ceasefire. As a coalition group, the UNFC could strengthen the negotiating position of the NSAGs. ${ }^{200}$ Starting from December 2011, the new peace process could bring ceasefire achievements to some extent. However, ethnic leaders remained suspicious of the government's commitment to peace, in part because of the resumption of hostilities in Kachin State after a 17-year-old ceasefire.

In reality, this is the most critical period for both the new government and the NSAGs. The end of the six-decade long civil war is essential to Thein Sein's government to resolve its legitimacy crisis. For the NSAGs, it is the best chance to

\footnotetext{
197 U Aung Thaung (a former minister of industry) is Secretary-1 of the USDP and a Lower House representative of Thaung Tha constituency in Mandalay Division. $U$ Thein Zaw (a former minister of communication) is a Central Executive Member of the ruling USDP and a Lower House representative of Myitkyina constituency in Kachin State.

${ }^{198}$ Min Zaw Oo (2014), pg-17

${ }^{199}$ Keenan (2012)

${ }^{200}$ Keenan (2014)
} 
re-enter the political mainstream, and address the grievances and expectations of their communities. Compared to the previous peace initiatives in the 1990s, the current approaches focus on the political matters, in addition to the military and economic issues. In this regard, both parties are hoping to build a genuine and sustainable peace after six decades of violence and underdevelopment. However, there are still key challenges that the main negotiators should be aware of.

\section{Key Challenges to the Peace Process}

The current peace process in Myanmar has the best opportunity to resolve the ethnic conflicts since 1962. Conditions for civilians have generally improved as a result of the ceasefire talks between the government and the NSAGs. However, there are still challenges for both parties to engage in a genuine peace talks because the root causes that lie at the center of the conflicts are not easily resolved.

Among these challenges, building "trust" is the most challenging matter for both parties as a consequence of the deeply-rooted structural problems. After decades of conflicts and inequalities, trust on the government is very limited and ethnic leaders are doubtful of the government's true willingness to bring peace to all parts of the country. $^{201}$ Therefore, stopping the ongoing hostilities in the northern part of Myanmar is an important task for the government because the whole peace process could be jeopardized unless this conflict is resolved.

Another significant challenge concerns the Myanmar Army's commitment to the peace process. $^{202}$ A key concern is whether the Myanmar Army is willing to agree the agenda and agreements negotiated by the government's peace-makers. For instance, the Tatmadaw continued to launch an offensive attack in Kachin state even while a nationwide ceasefire talk was being held. Although the Deputy Commander in Chief of the Myanmar Army was included in the Committee for Union Peace Making to represent the voices of the Army and to ensure its commitment to peace, clashes continued to occur even in the areas where truces have been agreed. Likewise, the commitment of some NSAFs is also questionable. ${ }^{203}$ Also, some ethnic

\footnotetext{
${ }^{201}$ Interview with Dr Than Ngwe (25 November 2014) in Nay Pyi Taw

${ }^{202}$ South (2012), p.17

${ }^{203}$ In some cases, local NSAG commanders have provoked the Tatmadaw- but in general government forces have been the more aggressive.
} 
leaders are worried about losing control of client population and popular support by engaging in the peace process. 204

The peace process of Myanmar is elite-driven so that the government's peace initiatives could be troubled by conservative authoritarian institutional culture and the limited capacities of the negotiators. In reality, Myanmar's peace process is highly complex with a number of players involved, with a rapid changes occurring without much transparency. However, the ability of these actors to understand the needs of the communities is always puzzling. Despite of a large number of actors involved, the extent to which peace negotiations are "inclusive" is always questionable. In particular, it is notable that women are always excluded from the formal peace talks. In addition, there is no evidence that ceasefire negotiations or peace agreements have considered gender to be a salient issue. As a result, vulnerabilities of women who comprised up to more than half of the affected population are never addressed at the peace table. Therefore, the next chapter will try to analyze the role of women in the peace process.

${ }^{204}$ South (2012), p.19 


\section{Chapter Five: Women in Myanmar's Peace Process}

In November 2013, Nobel Peace Prize winner, Ms Laymah Gbowee, gave a talk to the National Women's Dialogue forum in Myanmar, entitled 'Peace must hear voices of women". She claimed that all issues related to women must be addressed in the peace process because women are often the hardest-hit by conflict and suffer disproportionately from the impacts of armed conflicts. ${ }^{205}$ Although there has been increasing awareness of the importance of a gender perspective among stakeholders and civil societies in Myanmar, both the government and the ethnic armed organizations still fail to consider gender mainstreaming in their peace initiatives. In other words, women are still discriminated against and excluded from the peace processes. This chapter provides an overview of this exclusion and identifies the real costs of this discrimination when it comes to building a sustainable peace.

\section{Gender Analysis on the Current Peace Process}

Cherry Thein argues that Myanmar's peace processes need to be gender-sensitive because conflicts have profound impacts on gender relations. ${ }^{206}$ As a consequence of decades-long armed conflicts in Myanmar, gender roles have changed among ethnic women and men from conflict-affected areas. When men and boys are engaged in fighting, their traditional roles as heads of households, income generators and breadwinners are taken by women and girls in additional to the prescribed responsibilities such as nurturers and caregivers in order to protect and support their families. ${ }^{207}$ Furthermore, there is evidence that women and girls face different forms of violence that are closely linked to their gender roles in society and community ${ }^{208}$. Thus, every stage of peace process in Myanmar must take the gender perspective into account in order to assure a genuine and sustainable peace building which could guarantee greater gender equality in post-conflict situations.

According to the United Nations "peace includes not only the absence of war, violence and hostilities, but also the enjoyment of economic and social justice, equality and the entire range of human rights and fundamental freedoms within

\footnotetext{
${ }^{205}$ Thein (2013)

${ }^{206}$ KOFF (2012), p. 1

${ }^{207}$ O'Shannassy (2000), p. 17

${ }^{208}$ Shan Women's Action Network (2012)
} 
society". 209 This interpretation reflects women's views about their lives and gender roles as affected by conditions of war and peace. Therefore, the exclusion of women lead to a situation where the experiences of women are being overlooked, as the voices of women are absent or marginalized. As a result, the peace process will not be meaningful to the whole community.

Under Myanmar's military government, peace processes were solely negotiated and agreed among military leaders of conflicting parties without the participation of civil society. The peace talks mainly focused on the military issues, but never emphasized the roles and rights of women. Agreements were never publicized, and the details were always kept secret. In contrast, the current peace initiatives are technically open with media access. ${ }^{210}$ In recent years, the inclusion of women in peace process of Myanmar has become more prominent as a result of increased activism.

Nevertheless, Myanmar's peace processes remain gender-blind since women are still largely absent and marginalized in the peacemaking policies.

According to the Civil Society Forum of Peace in September 2011, Myanmar's peace process today is a top-down process with almost lack of the participation of civil society ${ }^{211}$. Women in particular are under-represented at the formal peace talks. The peace teams established for peace negotiations are almost exclusively maledominated. For example, there are no women in the 12-member Union Level Peace Committee (ULPC) and only 2 women are included in the 52-member Union Peace Working Committee (UPWC). ${ }^{212}$ Even the Myanmar Peace Center (MPC), a thinktank which facilitates all peace activities, fails to acknowledge the importance of women's participation in peace negotiations. ${ }^{213}$ At a meeting with the Women League of Burma's delegation [when?], the government's chief peace negotiator Minister Aung Min promised that women's involvement in the ongoing peace processes would be on the agenda during upcoming negotiations. However, women's groups expressed their concerns that there is a tendency for women to be invited to

\footnotetext{
${ }^{209}$ United Nations (1993), p. 5

${ }^{210}$ Information of the current peace process are open to the media. They can freely report and interview actors involved in the peace process. Also, public announcements of the peace talks are published in newspapers and broadcasted on state televisions.

${ }^{211}$ Statement of the Civil Society Forum of Peace (September 2011)

212 Khen \& Nyoi (2014), p. 22

${ }^{213}$ Interview with U Hla Maung Shwe (24 December 2015) in Yangon
} 
meetings just to be present, but those same people are denied opportunities for active participation. $^{214}$

While gender mainstreaming aims at eliminating gender-based discrimination in politics, the invited women need to truly represent women in Myanmar and actively participate in the negotiations. However, in reality, the only active participants are men. In an interview Daw Doi Bu, one of only two women in the UPWC, said her experience was that her presence at the UPWC was just superficial, and her active participation was denied by the head of the team because of being a female, claiming that it was not easy for women to travel to places where the talks were being held. ${ }^{215}$ As a Kachin woman who could build a good relation with the Kachin Independence Organization (KIO), Daw Doi $\mathrm{Bu}$ is keen to be part of negotiation in Kachin state. But in the small number of meetings that she was invited to attend, she was only allowed to speak very briefly. Subsequently, she was excluded from later peace talks although Daw Mi Yin Chan, her only female colleague in UPWC, was invited. ${ }^{216}$

Not everyone shares this view. According to Mi Yin Chan, an MP from the ruling USDP party said gender issues should not be discussed currently because they could undermine the ongoing ceasefire talks in which military and security affairs should be the priority. She expressed that these issues should be discussed at the political dialogue. ${ }^{217}$ However, Daw Susanna Hla Hla Soe, Director of Karen Women Group, expressed that "it is almost impossible to discuss about the gender issues such as violence against women during conflicts and women's rights unless these issues are not addressed at the ceasefire negotiation stage. Without gender equality, justice which is a necessary condition of peace is not guaranteed". 218 This view is also shared by Daw Khon Ja, founder of Kachin Peace Network, who said that "only justice guarantee lasting peace". She also expressed that "I do not believe in "eternal peace" which is frequently used by the government. As long as humans exist, there will be conflict. What we need is "justice" to prevent all kinds of conflicts". 219

\footnotetext{
${ }^{214}$ Democratic Voice of Burma (2014)

${ }^{215}$ Interview with Daw Doi Bu (27 November 2014) in Nay Pyi Taw

216 ibid

${ }^{217}$ Interview with Daw Mi Yin Chan (27 November 2014) in Nay Pyi Taw

${ }^{218}$ Interview with Daw Susanna Hla Hla Soe (13 January 2015) in Yangon

${ }^{219}$ Interview with Daw Khon Ja (13 January 2015) in Yangon
} 
The current peace process has three steps. First, the government's peace team and the NSAG settle on a basic state level agreement, agreeing to cease hostilities and to open liaison offices. Then, this is followed by a union level dialogue where issues of common concerns are discussed in more detail. Finally, a peace agreement will be signed in the Parliament. ${ }^{220}$ Currently, the peace process has been stuck in the condition of ceasefire negotiations due to the resumed fighting in some ethnic areas. Dr Than Ngwe from National League of Democracy pointed out that the lack of "trust" between the government and the NSAGs is the main reason why the current ceasefire negotiations could not move to next step, political dialogue. ${ }^{221}$ This view was shared by Dr Naw Rebecca Htin, an expert from MPC, who said that "we could not move forward from the stage of ceasefire negotiation unless "trust" could be built between negotiating parties". 222

At the same time, some interviewees expressed concerns that women could be spoilers in the peace processes because their experiences and vulnerabilities during conflicts could lead to a desire of revenge for themselves, their families and community. But in reality, being the most vulnerable groups during conflicts, women seem primarily concerned with preventing outbreak of the conflicts and hostilities. Moon Nay Li, Coordinator for the Advocacy Team of Karen Women's Action

Network, argues that women could provide suggestions for conflict resolution based on their experiences during conflicts. ${ }^{223}$ When women address the gender issues such as violence against women and girls during conflicts committed by military perpetrators, women do not want "revenge". In times of transnational justice, women emphasize the emergence of a system that could guarantee the protection and support for the rights and roles of women and girls in the post-conflict situations, according to Daw Susanna Hla Hla Soe, director of Karean Women Empowerment Group. ${ }^{224}$ Dr Nyo Nyo Thin, Member of Parliament from Yangon Division, said that, "peace is a situation which guarantees the women's participation, equality and security". She firmly believes that women's issues and suffering can be addressed and represented only by women. She expressed that "the exclusion of women from peace table is directly linked to the men's concern about these issues.... If women are included in

\footnotetext{
${ }^{220}$ Burma Partnership (2012)

${ }^{221}$ Interview with Dr Than Ngwe (26 November 2014) in Nay Pyi Taw

${ }^{222}$ Interview with Dr Naw Rebecca Htin (2 January 2015) in Yangon

${ }^{223}$ Moon Nay Li in Dateline Irrawaddy (2014)

${ }^{224}$ Interview with Daw Susanna Hla Hla Soe (13 January 2015) in Yangon
} 
the peace table, they will definitely raise these gender issues such as rapes and violence against women which men negotiators consider to be sensitive". 225

In this regard, one of the causes of the failure to include gender issues can be described as the fact that the current peace process is now at the stage of ceasefire discussions which are more related to military concerns rather than the gender issues. The objective of the ceasefire negotiations is to stop fighting or to end hostilities between the two conflicting parties so that there is no role for addressing gender issue. Dr Sui Khar, Assistant General Secretary of the Chin National Front, explained that the CNF's ceasefire negotiation team does not include women and is not ready to consider gender issue at the moment, but at least 30 percent presence of women at all levels will be assured for political dialogue. ${ }^{226}$ It seems that the Nationwide Ceasefire Coordination Team (NCCT) ${ }^{227}$ is also unwilling to discuss the gender issues at the peace negotiations ${ }^{228}$. In a meeting with the Women League of Burma $(\mathrm{WLB})^{229}$, the NCCT leaders told them to forget the incidents and forgive the perpetrators. But, as Tin Tin Nyo, secretary of the WLB, said, "it is not right to ignore the truth when we are peace building stage". She noted that "women required greater legal protection", referring to the issue of gender violence in conflict zones. $^{230}$

In terms of membership, both the government and the NSAG peace structures (teams) are male-dominated. From the government's side, only two female parliamentarians from the Lower House are included into the Union Peacemaking Working Committee (UPWC). ${ }^{231}$ As above noted, their active participation and representation of the women population in the country are limited by their male counterparts. Likewise, women are not well integrated into the peace negotiation teams of most of the NSAGs. Out of 16 NSAGs (as of 30 September 2013) which

\footnotetext{
${ }^{225}$ Interview with Dr Nyo Nyo Thin (16 January 2015) in Yangon

${ }^{226}$ Dr Sui Khar in Khen \& Nyoi (2014), 23

${ }^{227}$ The NCCT, composed of 13 members form member organizations, represents 17 NSAGs in dealing with UPWC for ceasefire negotiations.

${ }^{228}$ Interview with U Hla Muang Shwe(24 December 2014) in Yangon

${ }^{229}$ WLB is an umbrella organization compromising 12 already-existing women organizations of different ethnic backgrounds from Myanmar.

230 Nyein Nyein (2014)

${ }^{231}$ They are Daw Doi Bu from N'Jang Yang constituency in Kachin State (Unity and Democracy Party of Kachin State) and Mi Yin Chan from Kyaikmaraw constituency in Mon State (Union Solidarity and Development Party). They are also members of National Races Affairs and Internal Peace Making Committee which is composed of 11 members.
} 
have entered into the ceasefire or peace negotiation with the government, only three groups (the Karen National Union (KNU), Karenni National Progressive Party (KNPP) and New Mon State Party (NMSP)) have or had female members in their negotiation teams. From 2011 to 2012 while Padoh Naw Zipporah was serving as General Secretary, the KNU included at least three women in their ceasefire negotiation team. Mi Sar Dar, a central Committee member of the NMSP, was the only women in the NMSP's ceasefire negotiation team. The KNPP has a women, Maw Oo Myah, Religious and Culture Minister of the KNPP. ${ }^{232}$ But at the national level, Mra Raza Lin, a Central Committee Member of Arakan Liberation Party, is the only a women representative of the Nationwide Ceasefire Coordination Team (NCCT).

In practice, the negotiation teams from both sides are composed of high-ranking decision-making men. In Myanmar, the authoritarian and militarized nature of all conflicting parties has restricted the roles of women in political participation. In this regard, another explanation of the lack of women in peace teams could be the lack of women in wider decision-making levels. In other words, the current peace process is male-dominated because men occupy decision-making roles in every organization, according to Daw Susanna Hla Hla Soe. ${ }^{233}$ This view is echoed by Daw Khin Hmwe Lwin, a female Parliamentarian from the Lower House, that "under-representation of women at the peace table could be explained by their lack of access to the decisionmaking positions". 234 Thus, Mi Yin Chan, a USDP member of National Races Affairs and Internal Peace Making Committee commented that, "according to the current situation, we cannot conclude that women are excluded from the peace table because two women are included in the 11-membered peacemaking committee while women could hold only 7.8 percent of seats in the Lower House". 235

It is necessary to integrate a gender perspective in all reconstruction processes to ensure the more equitable and sustainable society. Peace processes need to hear the voices of women and consider their issues in order to establish gender equality in post-conflict situations. However, both the government and the NSAGs have failed to put a gender perspective in their peace processes. The case studies of the ceasefire agreements with four NSAGs (CNF, KNU, NMSP and RCSS) show that the gender

\footnotetext{
${ }^{232}$ Khen \& Nyoi (2014), pp.20-21

${ }^{233}$ Interview with Daw Susanna Hla Hla Soe (13 January 15) in Yangon

${ }^{234}$ Interview with Daw Khin Hmwe Lwin (26 November 2014) in Nay Pyi Taw

${ }^{235}$ Interview with Mi Yin Chan (27 November 2014) in Nay Pyi Taw
} 
issues are completely ignored and the women participation in the negotiations is significantly low. ${ }^{236}$ Only two groups, the CNF and the KNU have a policy to include 30 percent of women's participation at all levels in the upcoming political dialogue. On the government side, the MPC does not have such policy for gender mainstreaming although there are promises to increase women participation in the upcoming political dialogues. However, women's groups are worried that their concerns will not be addressed unless these issues are discussed at the ceasefire negotiations stage. The inclusion of women at the peace table is important for two main reasons which include addressing the violence against women during conflicts and ensuring the gender equality in post-conflict situations. In this regard, choosing strong women's advocates is really important. According to Dr Nyo Nyo Thin "the outspoken women were never incorporated into the peace team, because the male negotiators just want to include the women who listen to them and never raise the gender issues at the table". 237

In October 2000, the United Nations Security Council formally adopted the resolution 1325 which specifically calls for the inclusion of women at the peace table and their involvement in decision-making. This resolution addresses not only the serious impacts of conflicts on women and girls, but also the crucial role of women in peace-building, peace-keeping and post-conflict reconstruction. But Myanmar has not adopted or implemented a national action plan on this and following resolutions. In the absence of the nation plan to implement this resolution, the peace processes fail to mainstream a gender perspective in Myanmar.

From the optimistic view, Myanmar has ratified the Convention on the Elimination of All Forms of Discrimination against Women (CEADAW) since 1997. ${ }^{238}$ In March 2003, the Myanmar government adopted the National Strategic Plan for the Advancement of Women (NSPAW) in empower women and to ensure their rights. ${ }^{239}$

Myanmar also signed the Declaration to End Sexual Violence in Conflict in June 2014. This declaration contains practical and political commitments to end impunity, promote accountability, and provide justice and safety for victims of sexual violence

\footnotetext{
${ }^{236}$ Khen \& Nyoi (2014), pp.20-21

${ }^{237}$ Interview with Dr Nyo Nyo Thin (16 January 2015) in Yangon

238 ibid

${ }^{239}$ The Irrawaddy (2013)
} 
in conflicts. $^{240}$ However, it appears that the Myanmar government has not implemented the declaration despite its commitments. No serious action has been taken to end impunity for rape by the Tatmadaw. Reportedly, more than 100 rape cases have been documented since the beginning of the civilian government. More importantly, the Myanmar government refuses to acknowledge and take responsibilities for these human rights abuses. ${ }^{241}$ The Chief of the Defence Force, Senior General Min Aung Hlaing said in an address to mark Armed Forces Day in March 2013, "We are a military that adhere not only civil and martial laws and regulations, but also to the Geneva Convention..... Since we trained our Tatmadaw men to acknowledge and adhere to the Geneva Convention, our Tatmadaw have never committed war crimes and soldiers who (committed punishable acts) have had effective action taken against them according to military regulations". ${ }^{242}$ In the absence of acknowledgement from the Tatmadaw, the government needs to change its political approach to the peace process in order to end abuses. Without women's participation, it is less possible to achieve a genuine peace and to put an end to sexual violence because the current male-dominated peace negotiations are likely to preserve structural gender inequality while excluding a critical gender perspective on peace and conflict.

Although women are excluded from the current stage (ceasefire negotiation) of the peace process, there are some hopeful signs they may be included in the political dialogue stage where common concerns are going to be discussed in detail. In this regard, women need to enhance their capacity for effective participation. Traditionally, women are trained to take responsibilities of the households while men are encouraged to take part in public activities such as politics. That is why, in comparison with their female partners, men generally could better engage in political matters like the peace process, according to U Hla Maung Shwe, a senior consultant from the MPC. ${ }^{243}$ Dr Naw Rebecca Htin from MPC also commented that "the minimal inclusion of women at the peace table is closely related to their lack of capacity and experience in the area (peace process)". ${ }^{244}$ It is undeniable that men are more experienced about politics and peacebuilding, but the exclusion of women just

\footnotetext{
${ }^{240}$ Michael (2014)

${ }^{241}$ Women League of Burma (2014), p. 7

${ }^{242}$ Min Aung Hlaing in Women League of Burma (2014)

${ }^{243}$ Interview with U Hla Maung Shwe (24 November 2014) in Yangon

${ }^{244}$ Interview with Dr Naw Rebecca Htin (2 January 2015) in Yangon
} 
because of their lack of formal experience and capacity is unreasonable. Women can be empowered through capacity building programs. At the community level, women are the main agents for peacebuilding. Women can understand and sympathize with the suffering of their community. In this regard, women could find the best solutions to cure the trauma of their community. ${ }^{245}$ In an interview, Daw Nan Say Awar, a MP from Phalon-Sawaw Democratic Party (PSDP) provided concrete examples of this, saying that "women are good at monitoring the implementation of the ceasefire deals, and rehabilitation for the community after the ceasefire is important, so women are needed to be included in peace talks". 246

In general, it could be said that women's participation at the formal peace table is not encouraged at the current stage of ceasefire negotiations, but there are possibilities for increased women participation in the future process. This may be because until recently there was no connection and cooperation between women's organizations which focus on the development of women's rights issues, and peace organizations which mainly dealt with the armed groups and mediators (who are mostly men). These two movements have not aligned each other for a long time. Lahtaw and Raw (2012) point out the two factors that motivated the change in women's perspectives on peace processes. First, the formation of women's networks like Women Organizations' Network (WON), Karen Women Action Network (KWAN), Karen Women Action Group (KWAG) and the ethnic-ethnic based women's organizations such as the Karen Women's Organization (KWO) and the Shan Women's Human Rights Group. ${ }^{247}$ These networks organized the signature campaign which called for a nationwide ceasefire and stopping armed hostilities in Kachin states. ${ }^{248}$ Women's groups led Peace Day march in Yangon [in date???] and around the country and asked for the government to recognize ethnic women's rights and urged the establishment of a federal union. ${ }^{249}$ Women activists also led peaceful protests in Chin State to call for an immediate end to sexual violence against ethnic women. 250 The first national level seminar on Women, Peace and Security (UNSCR 1325) was jointly held by the Women Organizations' networks (WON) and Nyein (Shalom)

\footnotetext{
${ }^{245}$ Interview with Dr Than Ngwe (26 November 2014) in Nay Pyi Taw.

${ }^{246}$ Interview with Daw Nan Say Awar $(25$ November 2014) in Nay Pyi Taw

${ }^{247}$ Ibid, 13

${ }^{248}$ Women League of Burma (2012)

249 Democratic Voice of Burma (2014)

${ }^{250}$ Thang (2014)
} 
Foundation in early 2012. ${ }^{251}$ Furthermore, women organizations released reports about the human rights abuses which include allegations of sexual violence against ethnic women in conflict areas and called for justice for the victims.

Second, the changing political environment in Myanmar has also caused a change in women's perspective on peace process. The Thein Sein government initiated political transition and peace process in order to attract international attention and recognition. In this regard, its peace initiatives have been closely watched by the international community and there are expectations that they should be more transparent and inclusive than previous peace processes under the military regime. ${ }^{252}$ Women's advocacy groups have taken this opportunity to enhance the role of women by demanding for the women's inclusion at the peace table. Historically, women are less engaged in political affairs so that they are excluded from decision-making positions despite their capabilities and skills. Therefore, the participation in formal peace process could pave a track for women to re-engage in the fields of politics and decision-making. Daw Khon Ja, peace activist and founder of Kachin Peace

Network, said that "women are capable and skillful to take part in politics, however, traditional gender stereotypes restrict them from effective participation so that women must find a mechanism to re-enter to the areas of politics. Their inclusion at the formal peace tables is one of the solution". 253

Although there are opportunities open for women activists to raise their voices and address concerns for the victims of the conflicts, their access to financial and information resources, human and organizational capacity and media support are still limited. $^{254}$ Nevertheless, a growing number of initiatives have highlighted the importance of women's participation in peace processes and strengthened the collaborative effort of women in addressing Myanmar's armed conflicts.

\section{Challenges to women's participation in formal peace process}

Peace and national reconciliation are frequently stated as central goals of President Thein Sein's administration. The new government has taken various initiatives in order to bring a lasting peace between the Tatmadaw and the NSAGs. Despite these

\footnotetext{
${ }^{251}$ Lahtaw \& Raw (2012), p. 13

${ }^{252}$ Ibid

${ }^{253}$ Interview with Daw Khon Ja (13 January 2015) in Yangon

${ }^{254}$ Lahtaw \& Raw (2012), p. 13
} 
attempts, the current peace process does not create a space for women's participation. There are many challenges to a greater role for women, including their prescribed gender roles and stereotypes, deeply rooted cultural norms, lack of legislative support, resources and capacity.

Very often, women's access to the area of politics and conflict resolution is confronted with traditional patriarchal values and cultural barriers. In Myanmar, the culture is very patriarchal with the concept of "phon", a Myanmar word which means power, glory and holiness. This concept is used as the ground of social, political and religious hierarchy to legitimize men's headship and women's subordinated role at home and society. This is also fundamental in the political hierarchy in which men are favored and women are oppressed. ${ }^{255}$ Daw Za Tlem, member of the Phythu Hluttaw, mentioned in an interview that "support from the family is really important for effective participation in politics. Our society and culture support men to take part in politics, but women are not encouraged in the same way... if a woman try to involve in politics, her husband will not support her because men in Myanmar usually think of women as apolitical". 256

In addition, some traditional ethnic norms also block women's inclusion processes since women are not traditionally meant to take part in political negotiation. As noted by Dr Nyo Nyo Thin, "Women are sometimes included in meetings and negotiations, but their actual role is to prepare for the ceremony, not to truly represent at the process". She noted that even the structures of the Myanmar National Women's Affairs Committee and the Myanmar Women's Affairs Federation (MWAF) ${ }^{257}$ are male-dominated. "These government-run women organizations do not understand gender mainstreaming. Women who represent at these organizations are wives of the Tatmadaw Generals. So, people generally accept that these organizations are doing "wives' affairs" rather than "women's affairs". These organizations failed to build trust with the women in the country", said Dr Nyo Nyo Thin. ${ }^{258}$

Burmese history also indicates that the roles of women are largely associated with private life rather than public sphere. Women who are poets, artists or mothers of

\footnotetext{
${ }^{255}$ Nwe (2009), pp. 131-139

${ }^{256}$ Interview with Daw Za Tlem (25 November 2014) in Nay Pyi Taw

${ }^{257}$ MNWAC and MWAF are government-organized non-governmental organizations which are formed by the Tatmadaw leaders and run by their wives.

${ }^{258}$ Interview with Dr Nyo Nyo Thin (16 January 2015) in Yangon
} 
great kings are regarded as "respectable characters" in society while women who tried to get involved in politics are recorded as villains of the history. ${ }^{259}$ Traditional culture and religion (especially Buddhism) also shape the leadership roles in which women are not considered to have a role in politics and decision-making. "Even if they are assigned to take leadership positions, the traditional stereotype makes women hesitant because they lack self-confidence to enter public life", said Daw

Than Ngwe. ${ }^{260}$ Mi Kun Chan Non, a prominent Mon women leader, commented that "according to our cultural norms and values, we want men to be leaders and women to be those who sit around men for support. Men have to decide and lead, women have to obey and follow. This is how we are being socialized, what we have internalized". 261 Even in the conflict areas, majority of women and men regard that the peace process is political so that it should be dealt by political and military leaders. ${ }^{262}$ Women do not consider rape as gender discrimination, but as a problem of "fate" in the society. In most cases of rape, women are blamed for wearing inappropriate dress and going to inappropriate places. ${ }^{263}$

While the deeply rooted norms and values in the Myanmar society are blocking women's access to decision-making positions as well as peace tables, another explanation for their absence could be lack of a legal framework that supports women's participation in politics and formal peace talks. In recent years, women increasingly take part in politics. In contrast with the situations under the military rules, the roles of women are extensive, but they are still invisible. According to the 2008 constitution, there is no discrimination against women. But there is no provision included that encourages women's political representation. "The constitution, in essence, is not gender-sensitive at all” said Daw Khin Hmue Lwin. 264

At the same time, the constitution also says that "nothing shall prevent appointment of men to the positions that are suitable for men only". Referring to this issue, Dr Than Ngwe commented that "this provision is not clear, I don't know if there is

\footnotetext{
${ }^{259}$ Lahtaw \& Raw (2012), p. 8

${ }^{260}$ Interview with Dr Than Ngwe (26 November 2014) in Nay Pyi Taw

${ }^{261}$ Khen \& Nyoi (2014), p. 25

${ }^{262}$ Gender and Development Initiative (2012)

${ }^{263}$ Tofani (2012)

${ }^{264}$ Interview with Daw Khin Hmue Lwin (26 November 2014) in Nay Pyi Taw
} 
positions that women are not capable of. Women can also deal with defense and military issues. Thus, I accept this is just discrimination against women". 265

Article 59 (D) of the Constitution states that one of qualifications of the President or Vice-President "shall be well-acquainted with the affairs of the Union such as political, administrative, economic and military". Daw Shwe Shwe Sein Latt, a women activist, viewed this as a discrimination against women because women are not admitted to military service until recently. ${ }^{266}$ Furthermore, seats at the peace table are generally given to those who practice military power and who hold decision making positions in their respective organizations. Hence, women who were not admitted to military service are inevitably excluded from the process. In addition, lack of national action plan for the United Nations Security Council Resolution 1325 and lack of serious action to implement the CEADAW commitments don't help.

Daw Doi Bu and Dr Nyo Nyo Thin shared the same view that "we must enforce UNSCR 1325 and CEADAW in order to ensure women's participation at the peace table". 267

The authoritarian, oppressive and militarized nature of Myanmar's politics also reinforces women's subordination. "According to political situations in Myanmar under the military rules, those who are involved in the democracy movements were imprisoned. When men are kept in prisons, women could take care of the rest of the family. But if women are imprisoned, it is unlikely for men to keep the family. In the absence of women, family breaks down. In this regard, the bond between women and their love for family also discourage women to participate in politics. Consequently, women are excluded from decision-making positions as well as in peace processes" said Dr May Win Myint, member of the Pyithu Hluttaw. ${ }^{268}$ This view is added by Daw Khin Htay Kywe, member of the Pyithu Hluttaw, who said that "women are afraid of imprisonment and family break-down. This fear is not for themselves, but highly linked with their value on their family. Under the military rules, the junta oppressed not only the democracy activists, but also their family members too". 269

\footnotetext{
${ }^{265}$ Interview with Dr Than Ngwe (26 November 2014) in Nay Pyi Taw

${ }^{266}$ Interview with Daw Shwe Shwe Sein Latt (10 January 2015) in Yangon

${ }^{267}$ Interviews with Daw Doi Bu (27 November 2014) in Nay Pyi Taw and Dr Nyo Nyo Thin (16 January 2015) in Yangon

${ }^{268}$ Interview with Dr May Win Myint (26 November 2014) in Nay Pyi Taw

${ }^{269}$ Interview with Daw Khin Htay Kywe (26 November 2014) in Nay Pyi Taw
} 
Sometimes, women are labelled as potential spoilers because of the issues they bring to the peace table. Dr Aung Moe Nyo, member of the Amyotha Hluttaw, pointed out that "there is a gender stereotype that women cannot think and behave reasonable in accordance with time and situation. They may bring sensitive gender issues to the peace table while the process is undergoing a critical moment of building trust. In reality, women and their sufferings are neglected by both sides, and consequently, their capabilities and sufferings are not well-addressed". 270

Traditionally and culturally, boys are prioritized for schooling, but girls are not encouraged. More girls than boys are taken out of school to help their parents with the household chores. ${ }^{271}$ In this regard, women are said to lack knowledge, experience and capacity so that they are sidelined in formal peace processes. U Hla Maung Shwe argued that "the dynamics of our country depends on the capacity of the people rather than gender dimension. If women are capable, they will be part of it. The exclusion of women is due to their lack of knowledge and skills in this area". ${ }^{272}$ While women are not favored and even oppressed as a result of the cultural and traditional gender roles in Myanmar society, policies of institutions are not gender-sensitive. In this regard, women's access to decision making and formal peace talks is still far away.

\section{Bringing Gender Perspective to Myanmar's Peace Table}

What can be done about this? "Gender mainstreaming is a globally accepted approach to achieving gender equality [...] It makes women's as well as men's concerns and experiences integral to the design, implementation, monitoring, and evaluation of all policies and programmes". 273 According to Canadian International Development Agency, "gender mainstreaming in peacebuilding initiatives involves a concern for increasing women's participation, but it also goes further than that. This strategy looks at how to promote more equitable gender relations (political, economic and social) and the differential impacts of interventions on women, men, boys and girls". 274

\footnotetext{
${ }^{270}$ Interview with Dr Aung Moe Nyo (28 November 2014) in Nay Pyi Taw

${ }^{271}$ Than (2013), p. 52

${ }^{272}$ Interview with U Hla Maung Shwe (24 December 2014) in Yangon

${ }^{273}$ The Economic and Social Council in UN Women

${ }^{274}$ Woroniuk (2001)
} 
Conflict is a gendered activity, having differential impacts on women and men. In this regard, the peace process must mainstream gender perspective in all policies in order to ensure that women are not disadvantaged because of the peacebuilding activities, and to help them in improving their own situations. In the absence of gender mainstreaming in peace process, policies address the needs of women less adequately than those of men, or which result in deterioration in the situation of women. First of all, political and legal changes need to be checked for their impacts on gender equality. Constraints to women's meaningful engagement in decisionmaking process and formal peace initiatives require the revision of some existing legal frameworks (for instance, Myanmar's 2008 constitution), the enforcement of the agreed commitments (the CEDAW) and the adoption of specific commitments (the UNSCR 1325). Furthermore, a well-designed quota system is essential to ensure women's political representation and empowerment in post-conflict structures and processes. $^{275}$

Moreover, it is important to promote women's representation in institutions including government bureaucracies. Women could be empowered through training, education and capacity building programmes to become viable and confident candidates for leadership and decision-making positions. ${ }^{276}$ Furthermore, women's political representation could also be increased by the gender policies of the political party which create opportunities and space for women. ${ }^{277}$ In addition, the gender mainstreaming in peace process requires a change in the mindset which is deeply associated with traditional gender stereotypes and patriarchal values. ${ }^{278}$ It is also crucial to support institutional strengthening of women's peace organizations. These organizations should also be supported to promote the public debate about gender relations and cultural change including violence against women and women rights. ${ }^{279}$

Also, these organizations could raise the public awareness by launching campaigns and publishing research outcomes to promote women's participation in peacebuilding. 280

\footnotetext{
275 Interview with Daw Naw Say Hwa (25 November 2014) in Nay Pyi Taw, Dr Naw Rebecca Htin (21-2015) and Dr Nyo Nyo Thin (16 January 2015) in Yangon

${ }^{276}$ Interview with Dr Aung Moe Nyo (28 November 2014) in Nay Pyi Taw

${ }^{277}$ Interview with Daw Mi Yin Chan (27 November 2014) in Nay Pyi Taw

${ }^{278}$ Interview with Dr Nyo Nyo Thin (16 January 2015) in Yangon

279 Interview with Daw Shwe Shwe Sein Latt (10 January 2015) in Yangon

${ }^{280}$ Interview with Daw Khon Ja (13 January 2015) in Yangon
} 
Gender mainstreaming in the peace process is necessary because men cannot truly represent the women population and address their sufferings at the peace table. Bringing a gender perspective is essential in order to ensure gender equality in postconflict situations and processes. In the current peace process when both negotiating parties - state and non-state armed groups - are not willing to consider women's participation at the negotiation tables, women's peace organizations and activists urgently need to advocate for gender mainstreaming in peace process. Without that, the ongoing peace process is less likely to bring a genuine peace, which could guarantee equality and sustainability. 


\section{Conclusion}

After more than sixty years of armed conflicts, peace is a necessary condition for Myanmar which has fallen behind the rest of Southeast Asia economically and politically. Ceasefires have been reached with several ethnic armed groups, however, a sustainable peace has not yet been achieved, because some fighting has resumed and there has been a failure to address the root causes of ethnic division. In this regard, when it comes to negotiations at the formal talks, the essence of "peace" that Myanmar people demand is not just the end of hostilities and fighting, but a condition when equality and security are assured. Despite the new initiatives that aim to achieve a genuine peace, issues of equality and security are not still guaranteed. Most importantly, women and girls in the conflict areas are increasingly subjected to sexual violence even after the call for national reconciliation from the new civilian government.

In these situations, women's rights activists in Myanmar could link the ongoing risks of sexual violence in conflict zones with the exclusion of women from the formal peace talks. In their absence, the formal peace processes fail to address these gender issues so that the security and equality of women are not delivered. While women activists and organizations are trying to mainstream gender perspective in the peace processes of Myanmar, research for this thesis has found that key stakeholders and actors in the formal peace processes are reluctant to bring women participants to peace table. There is a widespread belief among the male negotiators from both government and ethnic armed groups' negotiating parties that women are "potential spoilers" to the peace talks, because they might bring sensitive gender issues to the table. These men also presume a lack of experience and knowledge about peace negotiations on the part of women. This view is mainly shared among all male interviewees, but most female participants strongly believe that women could better engage in the process as a result of their capacities in negotiating, conflict resolution and maintaining peace, and their fear for what an end to peace might mean. They firmly argue that women can effectively participate in the peace process if they are given the chance. And although there are different opinions about the inclusion of women at the stage of ceasefire negotiation, all interview participants agree that women must be incorporated and women's issues must be addressed in the political dialogue (the second stage of the peace process). In addition, they point out that the 
underrepresentation of women at the peace table is directly linked to the lack of women in the decision-making levels of the respective institutions. Furthermore, they share the same view that women's issues (for instance, violence against women and girls in conflict areas) will not be well-addressed in the absence of women and maintain that men could not truly represent and raise the voices of women.

Despite these shared views, there is little doubt that gender mainstreaming in the peace processes is not well-understood in Myanmar. Many think that gender only refers to women, and few stakeholders involved in the peace talks considered "gender mainstreaming" in their processes. Likewise, some women activists" demands for the inclusion of women at the peace table is solely for the sake of women's rights rather than seeing it as a substantive contribution to peace.

Gender mainstreaming is not a panacea for all of Myanmar's troubles. The root causes of decades the armed conflict lie in ethnic divisions rather than gender inequality. But perhaps the most significant finding of this study is that a sustainable peace cannot be achieved unless women are incorporated into the formal peace processes. Women's participation would help accelerate the current peace initiatives and achieving sustainable peace that could protect and ensure the equality of women in a post-conflict environment. 
Annex: Lists of Interviewees

\begin{tabular}{|c|c|c|c|}
\hline No & Respondents & Position & $\begin{array}{l}\text { Interview } \\
\text { Date }\end{array}$ \\
\hline 1 & Daw Nan Say Hwa & $\begin{array}{l}\text { Member of Pyithu Hluttaw from Hpa-an } \\
\text { Constituency from Karen State (Phalon-Sawaw } \\
\text { Democratic Party) }\end{array}$ & $25-11-2014$ \\
\hline 2 & Daw Za Talem & $\begin{array}{l}\text { Member of Pyithu Hluttaw from Thantlang } \\
\text { Constituencey from Chin State (Chin National } \\
\text { Party) }\end{array}$ & $25-11-2014$ \\
\hline 3 & $\begin{array}{l}\text { Daw Phyu Phyu } \\
\text { Thin }\end{array}$ & $\begin{array}{l}\text { Member of Pyithu Hluttaw from Mingalar } \\
\text { Taung Nyunt Constituency from Yangon } \\
\text { Division (National League for Democracy) }\end{array}$ & 26-11-2014 \\
\hline 4 & $\begin{array}{l}\text { Daw Khin San } \\
\text { Hlaing }\end{array}$ & $\begin{array}{l}\text { Member of Pyithu Hluttaw from Pale } \\
\text { Constituency from Mandalay Division (National } \\
\text { League for Democracy) }\end{array}$ & 26-11-2014 \\
\hline 5 & $\begin{array}{l}\text { Daw Khin Htay } \\
\text { Kywe }\end{array}$ & $\begin{array}{l}\text { Member of Pyithu Hluttaw from Mawlamyine } \\
\text { Constituency from Mon State (National League } \\
\text { for Democracy) }\end{array}$ & 26-11-2014 \\
\hline 6 & Dr Than Ngwe & $\begin{array}{l}\text { Member of Pyithu Hluttaw from Kalaw } \\
\text { Constituency from Shan State (National League } \\
\text { for Democracy) }\end{array}$ & 26-11-2014 \\
\hline 7 & $\begin{array}{l}\text { Daw Myint Myint } \\
\text { San }\end{array}$ & $\begin{array}{l}\text { Member of Pyithu Hluttaw from War-khe-ma } \\
\text { Constituency from Irrawaddy Division (National } \\
\text { League for Democracy) }\end{array}$ & 26-11-2014 \\
\hline 8 & $\begin{array}{l}\text { Daw Khin Hmwe } \\
\text { Lwin }\end{array}$ & $\begin{array}{l}\text { Member of Pyithu Hluttaw from Min Kin } \\
\text { Constituency from Sagaing Division (National } \\
\text { League for Democracy) }\end{array}$ & 26-11-2014 \\
\hline 9 & Dr May Win Myint & $\begin{array}{l}\text { Member of Pyithu Hluttaw from Mayangone } \\
\text { Constituencey from Yangon Division (National } \\
\text { League for Democracy) }\end{array}$ & 26-11-2014 \\
\hline 10 & $\begin{array}{l}\text { Daw Khin Wyne } \\
\text { Kyi }\end{array}$ & $\begin{array}{l}\text { Member of Pyithu Hluttaw from South Dagon } \\
\text { Constituency (National Democratic Force) }\end{array}$ & $26-11-2014$ \\
\hline
\end{tabular}




\begin{tabular}{|c|c|c|c|}
\hline No & Respondents & Position & \begin{tabular}{|l|} 
Interview \\
Date
\end{tabular} \\
\hline 11 & \begin{tabular}{|l} 
Daw Mi Yin Chan \\
\end{tabular} & $\begin{array}{l}\text { Member of Pyithu Hluttaw from Kyaikmaraw } \\
\text { Constituency from Mon State (Union Solidarity } \\
\text { and Development Party) } \\
\text { Member of Union Peace Making Committee }\end{array}$ & 27-11-2014 \\
\hline 12 & Daw Doi Bu & $\begin{array}{l}\text { Member of Pyithu Hluttaw from N' Jang Yang } \\
\text { Constituency from Kachin State (Unity and } \\
\text { Democrcy Party- Kachin) } \\
\text { Member of Union Peace Working Committee }\end{array}$ & $27-11-2014$ \\
\hline 13 & $\begin{array}{l}\text { Dr Zaw Myint } \\
\text { Maung }\end{array}$ & $\begin{array}{l}\text { Member of Pyithu Hluttaw from Kyaukpadaung } \\
\text { Constituency from Mandalay Divison (National } \\
\text { League for Democracy) }\end{array}$ & 28-11-2014 \\
\hline 14 & Dr Aung Moe Nyo & $\begin{array}{l}\text { Member of Pyithu Hluttaw from Pwint Phyu } \\
\text { Constituency from Magway Divison (National } \\
\text { League for Democracy) }\end{array}$ & $28-11-2014$ \\
\hline 15 & U Aung Kyi Nyunt & $\begin{array}{l}\text { Member of Pyithu Hluttaw from Taung-twin- } \\
\text { Gyi Constitutency from Magway Division } \\
\text { (National League for Democracy }\end{array}$ & $28-11-2014$ \\
\hline 16 & U Hla Maung Shwe & Senior Advisor, Myanmar Peace Center (MPC) & $24-12-2014$ \\
\hline 17 & $\begin{array}{l}\text { Dr Naw Rebecca } \\
\text { Htin }\end{array}$ & $\begin{array}{l}\text { Associate Director, Myanmar Peace Center } \\
\text { (MPC) }\end{array}$ & $2-1-2015$ \\
\hline 18 & $\begin{array}{l}\text { Daw Shwe Shwe } \\
\text { Sein Latt }\end{array}$ & $\begin{array}{l}\text { Director of Creative House (Capacity } \\
\text { Development for youths and women) }\end{array}$ & $10-1-2015$ \\
\hline 19 & Daw Kyi Kyi Mar & $\begin{array}{l}\text { Member of Yangon Division Parliament (Union } \\
\text { Solidarity and Development Party) }\end{array}$ & \begin{tabular}{|l|}
$10-1-2015$ \\
\end{tabular} \\
\hline 20 & $\begin{array}{l}\text { Daw Susanna Hla } \\
\text { Hla Soe }\end{array}$ & $\begin{array}{l}\text { Director of Karen Women Empowerment Group } \\
\text { and Co-coordinator of Karean Peace Network }\end{array}$ & $13-1-2015$ \\
\hline 21 & Daw Khon Ja & $\begin{array}{l}\text { Peace Activist and Founder and Coordinator of } \\
\text { the Kachin Peace Network }\end{array}$ & $13-1-2015$ \\
\hline 22 & \begin{tabular}{|l} 
Dr Nyo Nyo Thin \\
\end{tabular} & $\begin{array}{l}\text { Member of Yangon Division Parliament from } \\
\text { Bahan (2) Constituency }\end{array}$ & \begin{tabular}{|l|}
$16-1-2015$ \\
\end{tabular} \\
\hline
\end{tabular}




\section{B I B L I O G R A P H Y}

Anderlini, S. N. (2000). Women at the Peace Table: Making a difference. United Nations Development Fund for Women.

Anderlini, S. N. (2004). Peace negotiations and agreements. International Alert.

Anderlini, S. N. (2007). Women Building Peace: What they do, why it matters. Lynne Rienner Pub..

Anderlini, S. N. (2007). Women Building Peace: What they do, why it matters. Lynne Rienner Pub..

Apple, B. (1998). School for rape: The Burmese military and sexual violence. EarthRights International (ERI).

Aung, K. S. N. (2000). A Brief History of the National Democratic Movement of Ethnic Nationalities. Khaing Soe Naing Aung.

Baksh-Soodeen, R. (Ed.). (2005). Gender mainstreaming in conflict transformation: Building sustainable peace. Commonwealth Secretariat.

Barnett, M., Kim, H., O'donnell, M., \& Sitea, L. (2007). Peacebuilding: What is in a Name?. Global Governance: A Review of Multilateralism and International Organizations, 13(1), 35-58.

Bertolazzi, F. (2010). Women with a blue helmet: the integration of women and gender issues in UN peacekeeping missions. United Nations International Research and Training Institute for the Advancement of Women.

Blanchard, E. M. (2014). Gender, international relations, and the development of feminist security theory. Signs, 40(1).

Brock-Utne, B. (1985). Educating for peace: A feminist perspective. Pergamon.

Burma Partnership. (2012). We Have Seen This Before: Burma's Fragile Peace Proces.

Callahan, M. P. (2004). Making enemies: War and state building in Burma. NUS Press. 
Caprioli, M., \& Boyer, M. A. (2001). Gender, violence, and international crisis.Journal of Conflict Resolution, 45(4), 503-518.

Chaturvedi, M. (2004). Myanmar's Ethnic Divide: The Parallel Stuggle. IPCS Special Report 131

Cockburn, C. (2007). From where we stand: war, women's activism and feminist analysis. Zed Books.

Conover, P. J., \& Sapiro, V. (1993). Gender, feminist consciousness, and war.American Journal of Political Science, 1079-1099.

Dateline Irrawaddy 22082814 [Motion picture]. (2014). The Irrawaddy. Retrieved from https://www.youtube.com/watch?v=ztHONN87mcY

Democratic Voice of Burma (2014, September 22), Women Led Peace Day Marches in Rangoon. Retrieved from https://www.dvb.no/news/women-lead-peace-daymarches-in-rangoon-burma-myanmar/44340

Democratic Voice of Burma. (2014, February 12). Women urged to take part in peace process. Retrieved from https://www.dvb.no/news/women-urged-to-takepart- in-peace-process-burma-myanmar/37141

Eisler, R., \& Loye, D. (1986). Peace and feminist theory: New directions.Security Dialogue, 17(1), 95-99.

Elshtain, J. B. (1987). Women and war. University of Chicago Press.

Falb, K. L., McCormick, M. C., Hemenway, D., Anfinson, K., \& Silverman, J. G. (2013). Violence against refugee women along the Thai-Burma border.International Journal of Gynecology \& Obstetrics, 120(3), 279-283.

Fleiner, T., Kalin, W., Linder, W., \& Saunders, C. (2003). Federalism, decentralisation and conflict management in multicultural societies. Federalism in a changing world, 197-215.

Fukuyama, F. (1998). Women and the evolution of world politics. Foreign Affairs, 24-40.

Fukuyama, F. (2006). State-Building. London: Profile Books.

Galtung, J. (1964). An Editorial. Journal of Peace Research. 
Galtung, J. (1996). Peace by peaceful means: Peace and conflict, development and civilization (Vol. 14). Sage.

Galtung, J. (2005). Violence, peace, and peace research. Peace studies: Critical concepts in political science, 1, 21-52.

Ganesan, N., \& Hlaing, K. Y. (Eds.). (2007). Myanmar: state, society and ethnicity. Institute of Southeast Asian Studies.

Gender and Development Initiative. (2012). Different Needs and Rights of Women and Men from Conflict Affected Communities. GDI

Goldstein, J. S. (2001). War and gender: How gender shapes the war system and vice versa. Cambridge University Press.

Graver, M. (1993). Nationalism as political paranoia in Burma. Copenhagen: NIAS.

Heyzer, N. (2002). Combating trafficking in women and children: a gender and human rights framework. na.

Hlaing, K. Y., Taylor, R. H., \& Than, T. M. M. (Eds.). (2005). Myanmar: beyond politics to societal imperatives. Institute of Southeast Asian Studies.

International Crisis Group. (2011). Myanmar: A New Peace Initiatives (Vol. Asia Report N 214).

Jelsma, M., \& Kramer, T. (2012, April 5). Tackle Burma's Drug Problems. Retrieved from http://www.tni.org/article/tackle-burmas-drugs-problem

Jimenez, X., \& Langholtz, H. J. (2008). GENDER PERSPECTIVES IN UNITED NATIONS PEACEKEEPING OPERATIONS.

John, M. S. (2006). Feminism and Peace Studies Taking Stock of a Quarter Century of Efforts. Indian Journal of Gender Studies, 13(2), 137-162.

Keenan, P (2012). Establishing a Common Framework. Burma Center for Ethnic Studies, Briefing Paper No. 6.

Keenan, P (2014). Struggling For Peace. Burma Center for Ethnic Studies, Analysis Paper No. 8. 
Khen, S. I., \& Nyoi, M. Y. H. (2014). Looking at the Current Peace Process in Myanmar through a Gender Lens. Yangon: swisspeace and the Gender and Development Institute-Myanmar.

KOFF. (2012),Gender Dimensions of Conflict and Peacebuilding,swisspeace.

Kramer, T., \& Aronson, D. (2009). Neither war nor peace: The future of the ceasefire agreements in Burma. Transnational Institute.

Kumari, S. (2012). Burmese Refugee Women in India: Victims and Agents of Empowerment (Vol. 4). South Asian Journal of Peacebuilding.

Kuppuswamy, C. (2011, August 1). BURMA: ETHNIC CONFLICT AND THE REVIVED CIVIL WAR - ANALYSIS. Retrieved from _ http://www.eurasiareview.com/01082011-burma-ethnic-conflict-and-the-revivedcivil-war-analysis/

Lahtaw, J. N., \& Raw, N. (2013). Myanmar's Current Peace Processes: A New Role for Women?'. Yangon: HD Center.

Lall, M. (2009). Ethnic conflict and the 2010 elections in Burma. Chatham House.

Lehman, F. K. (1981). Military rule in Burma since 1962: a kaleidoscope of views. Maruzen Asia.

Lindsey, C. (2002). Women facing war. Refugee Survey Quarterly, 21.

Lindsey, C. (2004). Addressing the Needs of Women Affected by Armed Conflicts. Geneva: International Committee of the Red Cross.

Lintner, B. (1994). Burma in revolt. Opium, and Insurgency since n1948, Boulder, Bangkok: Westview, White Lotus.

Lists of ceasefire deals with the junta. (2004, January 1). Retrieved from http://www2.irrawaddy.org/research_show.php?art_id=444

Maoz, I. (2009). The women and peace hypothesis? The effect of opponent negotiators' gender on the evaluation of compromise solutions in the IsraeliPalestinian conflict. International Negotiation, 14(3), 519-536. 
McCarthy, B., Hagan, J., \& Woodward, T. S. (1999). IN THE COMPANY OF WOMEN: STRUCTURE AND AGENCY IN A REVISED POWER-CONTROL THEORY OF GENDER AND DELINQUENCY*. Criminology, $37(4), 761-789$

McKay, S. (2000, October). Gender justice and reconciliation. In Women's Studies International Forum (Vol. 23, No. 5, pp. 561-570). Pergamon.

Melander, E. (2005). Gender equality and intrastate armed conflict. International Studies Quarterly, 49(4), 695-714.

Mervis, Z., Eve, N., Florence, M., \& Caroline, M. (2013). The relationship between democracy and women participation in politics. Journal of Public Administration and Governance, 3(1), Pages-168.

Michael, S. (2014, June 10). Burma Joins Global Summit to End Sexual Violence in Conflict. Retrieved from http://www.irrawaddy.org/burma/burma-joins-global$\underline{\text { summit-end-sexual-violence-conflict.html }}$

Min, A. (2000). Cycle of Suffering. Bangkok: Human Rights Documentation Unit and Burmese Women's Union.

Moser, C. N., \& Clark, F. (Eds.). (2001). Victims, perpetrators or actors?: gender, armed conflict and political violence. Palgrave Macmillan.

Myoe, M. A. (2009). Building the Tatmadaw: Myanmar armed forces since 1948(Vol. 352). Institute of Southeast Asian Studies.

Nilsen, M. (2013). Will democracy bring peace to Myanmar?. International area studies review, 16(2), 115-141.

Nwe, A. (2009). Gender Hierarchy in Myanmar. RAYS, 10, 131.

Nyein, N. (2014, July 7). Ethnic Leaders and Women Brief Politicians on Peace Talks. Retrieved from The Irrawaddy, http://www.irrawaddy.org/burma/ethnic- leaders-women-brief-politicianspeace-talks.html

Oo, Z., \& Min, W. (2007). Assessing Burma's ceasefire accords. Institute of Southeast Asian Studies.

O'Shannassy, T. (2000). Burma's Excluded Majority: Women, Dictatorship and the Democracy Movement. CIIR. 
O'Shannassy, T. (2000). Burma's Excluded Majority: Women, Dictatorship and the Democracy Movement. CIIR.

Pateman, C. (1970). Participation and democratic theory. Cambridge University Press.

Peterson, V. (1998). Feminisms and international relations. Gender \& History, 10(3), 581-589.

Pilcher, J., \& Whelehan, I. (2004). 50 key concepts in gender studies. Sage.

Pillay, A. (2001). Violence against Women in the Aftermath. The Aftermath-Women in Postconflict Transformation.

Plümper, T., \& Neumayer, E. (2006). The unequal burden of war: The effect of armed conflict on the gender gap in life expectancy. International Organization,60(03), 723-754.

President U Thein Sein delivers inaugural address to Pyidaungsu Hluttaw. (2011, March 31). The New Light of Myanmar, p. 1.

Ruddick, S. (1989). Maternal thinking: Toward a politics of peace.

Sakhong, L. H. (2010). In Defence of Identity: The Ethnic Nationalities' Struggle for Democracy, Human Rights, and Federalism in Burma: a Collection of Writings and Speeches, 2001-2010. Orchid Press.

Sakhong, L. H. (2012). The 2008 Constitution and the Ethnic Issues: To What Extent Did It Satisfy the Aspirations of Various Ethnic Groups? Burma Center for Ethnic Studies, Analysis Paper No. 5.

Sakhong, L. H. (2012). The Dilemma of Military Ditatorship And Internal Peace in Burma. Burma Center for Ethnic Studies, Analysis Paper No. 3.

Sakhong, L. H. (2012). The Dynamics of Sixty Years of Ethnic Armed Conflict in Burma. Burma Center for Ethnic Studies, Analysis Paper No. 1.

Selth, A. (2002). Burma's armed forces: power without glory. Signature Books.

Shan Women's Action Network. (2002). Licence to rape. Retrieved December, 4, 2011. 
Shiva, V. (1988). Staying alive: Women, ecology and development. Zed Books.

Sideris, T. (2001). Rape in war and peace: social context, gender, power and identity. The aftermath: Women in post-conflict transformation, 142-158.

Silverstein, J. (Ed.). (1989). Independent Burma at forty years: six assessments(No. 4). Cornell University Southeast Asia Program.

Silverstein, J. (Ed.). (1993). The political legacy of Aung San (No. 11). SEAP Publications.

Smith, M. (1999). Burma: Insurgency and Ethnic Identity. London: Zed Books.

Smith, M. (2007). State of strife: the dynamics of ethnic conflict in Burma. Singapore: Institute of Southeast Asian Studies.

Smith, M. (2007). State of strife: the dynamics of ethnic conflict in Burma. Singapore: Institute of Southeast Asian Studies.

South, A. (2012). The politics of protection in Burma: Beyond the humanitarian mainstream. Critical Asian Studies, 44(2), 175-204.

South, M. A. (2013). Mon Nationalism and Civil War in Burma: the golden sheldrake. Routledge.

Steans, J. (1998). Gender and International Relations: An Introduction. Rutgers University Press.

Sterba, J. P. (1994). Feminist justice and the pursuit of peace. Hypatia, 9(2), 173187.

Strickland, Richard, and Nata Duvvury. "Gender equity and peacebuilding. From rhetoric to reality: finding the way. A discussion paper." (2003).

Taylor, L. (2003). " We'll Kill You If You Cry": Sexual Violence in the Sierra Leone Conflict. Human Rights Watch.

Tessler, M., \& Warriner, I. (1997). Gender, feminism, and attitudes toward international conflict: Exploring relationships with survey data from the Middle East. World Politics, 49(02), 250-281. 
Tessler, M., Nachtwey, J., \& Grant, A. (1999). Further Tests of the women and peace hypothesis: Evidence from cross-national survey research in the Middle

East. International Studies Quarterly, 43(3), 519-531.

Than, T. (2013). Women in modern Burma. Routledge.

Thang. T. Z. (2014, June 25). Protests calling for an end to raping ethnic women. Retrieved from http://www.chinlandguardian.com/index.php/chinnews/item/2177- protests-calling-for-end-to-raping-ethnic-women

The Irrawaddy. (2013, October 7). Burma Launches National Plan to Empower Women. Retrieved from http://www.irrawaddy.org/burma/burma-launchesnational- plan-empower-women.html

Thein, C. (2013, November 18). Peace Processes must hear voices of women, says Nobel winner. Retrieved from http://www.mmtimes.com/index.php/nationalnews/yangon/8807-peace-process-must-hear-voices-of-women-says-nobelwinner.html

Tickner, A. J. (1999). Searching for the Princess?. Harvard International Review,21(4), 44.

Tickner, J. A. (1992). Gender in international relations: Feminist perspectives on achieving global security. Columbia University Press.

Tinker, H. (1984). Burma: The Struggle for Independence, Vol II, from General Strike to Independence, 31 August 1946 to 4 January 1948.

Tofani. R. (2012, May 5). Women "Invisible" in Myanmar. Retrieved from http://www.globalissues.org/news/2012/05/05/13573

UN Women. Gender Mainstreaming. Retrieved from . http://www.unwomen.org/en/how-we-work/un-system-coordination/gendermainstreaming

United Nations. (1993), The Nairobi Forward-Looking Strategies for the Advancement of Women, New York.

United Nations. Secretary-General. (2002). Women, Peace and Security: Study Submitted by the Secretary-General Pursuant to Security Council Resolution 1325 (2000). United Nations Publications. 
Villellas Ariño, M. (2010). The Participation of Women in Peace Processes: The Other Tables. International Catalan Institute for Peace, Working Paper, (2010/5).

Walton, M. J. (2008). Ethnicity, conflict, and history in Burma: The myths of Panglong.

Ward, J., \& Marsh, M. (2006, June). Sexual violence against women and girls in war and its aftermath: realities, responses, and required resources. InSymposium on Sexual Violence in Conflict and Beyond (Vol. 21, p. 23).

Weber, A. (2006). Feminist peace and conflict theory. Encyclopaedia on Peace and Conflict Theory, 2-13.

Women League of Burma (2012, June 20), World Refugee Day (2012): Peace Signature Campaign. Retrieved from http://womenofburma.org/womens-leagueof- burma-peace-signature-campaign-photo-album/

Women League of Burma. (2004). System of impunity: Nationwide pattern of sexual violence by the military regime's army and authorities in burma. Chiangmai.

Women League of Burma. (2009). Reflections on CEDAW 2008. Chiangmai.

Women League of Burma. (2014). Same Impunity, Same Pattern.

Women, U. N. (2010). Women's participation in peace negotiations: Connections between presence and influence. New York.

World Conference on Women, \& United Nations. (1996). Report of the Fourth World Conference on Women: Beijing, 4-15 September 1995. na.

Woroniuk, B., \& Unit, P. (2001). Gender Equality and Peace Building: Operational Framework. Canadian International Development Agency (CIDA). Index, 157.

Yawnghwe, H. (2013). National Dialogue: Armed groups, contested legitimacy and political transition (pp. 44-49). 